\title{
Discharge and Sediment Transport in a River Basin. Assessment Before and After the Construction of a Dam at the Upper Basin Boundary
}

\section{George Paschalidis}

Aristotle University of Thessaloniki Faculty of Engineering: Aristoteleio Panepistemio Thessalonikes

Polytechnike Schole

Ilias Ilordanidis

Bhagwant University Department of Civil Engineering

Petros Anagnostopoulos ( $\sim$ anagnost@civil.auth.gr)

Aristotle University of Thessaloniki

\section{Original Research}

Keywords: River Basin, Discharge, Sediment transport, AGNPS, RUSLE, Dam

Posted Date: February 4th, 2021

DOI: https://doi.org/10.21203/rs.3.rs-170323/v1

License: (a) (1) This work is licensed under a Creative Commons Attribution 4.0 International License. Read Full License

Version of Record: A version of this preprint was published at Environmental Processes on July 24th, 2021. See the published version at https://doi.org/10.1007/s40710-021-00534-y. 


\title{
Discharge and sediment transport in a river basin. Assessment before and after the construction of a dam at the upper basin boundary
}

\author{
George Paschalidis
}

Department of Civil Engineering, Aristotle University of Thessaloniki, Thessaloniki, Greece.

\section{Ilias Iordanidis}

Department of Civil Engineering, Aristotle University of Thessaloniki, Thessaloniki, Greece.

Petros Anagnostopoulos

Department of Civil Engineering, Aristotle University of Thessaloniki, Thessaloniki, Greece.

Corresponding author: Petros Anagnostopoulos

Email: anagnost@civil.auth.gr

Tel.: +30-2310-995675 


\begin{abstract}
The purpose of this study is the evaluation of runoff and sediment transport in the basin of the Nestos River (Northern Greece) downstream of the dam of Platanovrisi, constructed in 1998. The model used for the simulation was AGNPS, which is based on the Revised Universal Soil Loss Equation (RUSLE), combined with a GIS interface. Two different simulations were conducted, one for the years 1980-1990 and another for the period 2006-2030, before and after the construction of the dam respectively. For the simulation for the period 1980-1990 existing meteorological data were employed, and the results were in good agreement with those of a different study (Hrissanthou, 2002). The simulation for the period 2006-2030 was based on rainfall and climatic data generated from the software packages GlimClim and ClimGen. The mean runoff was by $5 \%$ lower and the mean annual sediment yield by $20 \%$ lower than the corresponding values for the period 1980-1990.
\end{abstract}

Keywords: River Basin; Discharge; Sediment transport; AGNPS; RUSLE; Dam 


\section{Introduction}

Watersheds are often subjected to flooding, erosion and sedimentation hazards leading to environmental, social and economical complications. Sediment discharge consists mainly of soil erosion products of the watershed, discharged into the main stream of the basin. The prediction of the runoff and sediment yield (total sediment outflow per unit time) of a watershed has been an ambitious goal for a variety of scientists, such as engineers, hydrologists, geologists and others. In particular, estimation of sediment discharge in various temporal and spatial scales is a vital key point for the assessment and design of major hydraulic projects, such as hydroelectric dams and flood attenuation structures.

Computer modeling is considered to be a cost-effective tool for assessing the impact of agricultural management practices on water quality at a watershed scale. In order to simulate the main processes of sediment transport, three categories of models (empirical, conceptual and physically-based) have been developed (Kaffas \& Hrissanthou, 2015). Some common empirical models are the Universal Soil Loss Equation (USLE) (Wischmeier and Smith, 1978), the Musgrave Equation (Musgrave, 1947), the Dendy-Boltan Method (Dendy \& Boltan, 1976) and the Sediment Delivery Ratio (Renfro, 1975). Empirical models are created for certain conditions, from field measurements and observations. The most widely used empirical model is the Universal Soil Loss Equation (USLE). A revision of USLE is the Revised Universal Soil Loss Equation (RUSLE).

Conceptual models, such as the Sediment Routing Model (Williams \& Hann, 1978), the Discrete Dynamic Model (Sharma \& Dickinson, 1979) and the Agricultural Catchment Research Unit (Schulze, 1995) are a mixture of empirical and physically-based models.

Finally, physically-based models describe the natural procedure of streamflow and sediment transport in a basin (Merritt et al., 2003). Some examples of physically-based models are the: Areal Non-Point Source Watershed Environment Response Simulation (Beasley et al., 1980), Chemical Runoff and Erosion from Agricultural Management Systems (Knisel, 1980), Water Erosion Prediction Project (Laflen et al., 1991), and European Soil Erosion Model (Morgan et al., 1998).

Several non-point source (NPS) models have been developed to evaluate the sediment yield in a watershed (Binger et al., 1992). AnnAGNPS is a suite of models developed as a planning tool for forested or agricultural watersheds (Binger \& Theurer, 2001). It was developed jointly by the United States Department of Agriculture (USDA) Agricultural Research Service (ARS) and the USDA Natural Resources Conservation Service (NRCS).

In this paper, the Agricultural Non-Point Source Pollution Model (AGNPS) was used to predict runoff and sediment losses from a section of a predominantly forested watershed of Nestos River, located in Macedonia and Thrace, Northern Greece. In particular, the study area is the basin downstream of the hydroelectric dam of Platanovrisi, which is located approximately at the middle of the river's course inside the Greek territory (Fig. 1). The construction of the dam was completed in 1998. The area of the basin is $884 \mathrm{~km}^{2}$. Runoff and sediment yield were estimated at the location Toxotes, at the outlet of the study area.

Extensive rainfall and climate data, such as wind speed, relative humidity, temperature and solar radiation are necessary (Iordanidis, 2010). The use of the model as a prediction tool requires its calibration for the conditions in the study area. In the calibration process, the 
values of various parameters are adjusted, such that the measured values of runoff and sediment yield for a specific year approximate closely the values estimated by the model. The validity of the adjustment is confirmed, from the agreement between predicted and measured values of runoff and sediment yield in a different year. Two different simulations were conducted, one for the years 1980-1990 and another for the period 2006-2030. The simulation for the years 1980-1990 was conducted using recorded meteorological data, whereas the simulation for the period 2006-2030 was based on rainfall and climate data generated by two software packages, namely GlimClim and ClimGen.

\section{Materials and methods}

Soil detachment, deposition and transport are important factors when modeling sediment loads in watersheds. Detached soil particles, apart from their potential effect in filling of lakes and reservoirs, may transfer harmful contaminants in downstream watercourses. AGNPS is a sediment and pollutant load modeling module, designed for risk and cost/benefit analyses. It is a batchprocess, continuous-simulation, surface-runoff computer model which is suitable for studies of watersheds of this scale. The model was developed for the simulation of long-term sediment and chemical transport from forest or agricultural watersheds. The basic modeling components are hydrology, sediment, nutrient and pesticide transport (TR-55).

AGNPS is a daily time-step, distributed model, which enables the modeling of all different processes and parameters that affect sediment transport, allowing the creation of a detailed model of the study area (Binger et al., 1992). AGNPS is based on the Revised Universal Soil Loss Equation (RUSLE) combined with a GIS (Geographic Information System) interface for more convenient preparation of input data. RUSLE is a simple empirical model which is based on regression analyses of soil loss rates. It has the following structure, similarly to the USLE (Renard et al., 1997):

$A=R \cdot K \cdot L S \cdot C \cdot P$, where:

$A$ is the computed spatial and temporal average soil loss per unit area $[\mathrm{Mg} /$ (ha year)],

$R$ is the rainfall-runoff erosivity factor $[\mathrm{MJ} \mathrm{mm/(ha} \mathrm{h} \mathrm{year)];}$

$K$ is the soil erodibility factor $[\mathrm{Mg} \mathrm{h} /(\mathrm{MJ} \mathrm{mm})]$,

$L S$ is the slope length and steepness factor,

$C$ is the vegetation cover and management factor,

$P$ is the conservation support practices factor.

The $L S, C$, and $P$ values are dimensionless.

AGNPS is widely used because of its relative simplicity, robustness and ability to enable prediction of average annual erosion by multiplying several factors together, such as rainfall erosivity $(R)$, soil erodibility $(K)$, slope length and steepness $(L S)$.

A large amount of input data is necessary for the model setup. AGNPS simulates runoff and sediment transport from land to streams, as a result of storm flow. Runoff is calculated in the model using a variation of the Technical Release 55 (TR-55) method (NRCS, 2001). TR- 
55 employs simplified procedures to calculate runoff volume in small watersheds. A modified Einstein deposition equation, using the Bagnold suspended sediment formula for the transport capacity by particle size class, was used for the sediment transport in the watershed.

In order to facilitate the processing of spatial data, AGNPS provides an ArcView GIS interface, in which the GIS tools for terrain processing can be utilized (De Roo, 1998). The most important of these tools are the Digital Elevation Model (DEM) manipulation, the Digital Elevation Drainage Network Model (DEDNM) used for both the river basin discretization and the hydrologic network delineation, and the land use and soil texture data spatial input. (Iordanidis, 2010). It should be mentioned that the current version of AGNPS provides a built-in GIS interface, based on the MapWinGIS software suite.

\subsection{Watershed discretization}

Using the Digital Elevation Drainage Network Model (DEDNM) of AGNPS, the basin was discretised into cells and channel reaches. The discretisation was based on the critical source area (CSA) and minimum source channel length (MSCL) parameter values. Critical source area is the minimum area for which a cell can be generated, and minimum source channel length the minimum possible length for the generation of a channel reach. AGNPS offers the capability to use up to five different value pairs for the CSA and MSCL parameters.

AGNPS uses amorphous cells, each cell being a grouping of individual square grid elements, which collectively represent homogeneous hydrological response units. The number of amorphous cells or hydrologic response units representing a watershed depends on the size and spatial variability within the watershed. Since no significant variations within the basin were detected, the selected values for CSA and MSCL were 55 ha and $150 \mathrm{~m}$ respectively for the entire study area. Figure 2 presents the final discretisation of the study area into 1568 cells.

Cell landscape parameters were derived using a landscape analysis tool of AGNPS for topographic evaluation, drainage identification, watershed segmentation and sub-catchment parameterization (Binger et al., 1998). The cell attributes include the drainage area, average elevation, average slope, shallow flow slope and length, concentrated flow slope and length, and the $L S$-factor, a basic factor of Revised Universal Soil Loss Equation (RUSLE), which computes the effect of slope length and steepness on erosion (Van Remortel et al., 2001). In order to model the boundary of the basin after the construction of the dam, the digital elevation model of the study area was modified locally, and the discharge was represented as a point source of water.

The drainage network, comprising 699 channel reaches, is illustrated in Figure 3. The reach attributes include drainage area, contributing cells, receiving reaches, average elevation and channel slope and length.

\subsection{Land use data}

Land use data were acquired from the European Environmental Agency. This dataset is a raster-format, geo-referenced, categorized land cover data layer. The raster data were converted into shapefile format using ArcView version 9.3, and the AGNPS/ArcView interface was then used to determine the land use in each cell (Fig. 4). According to the 
existing land use data, the cells within the watershed were classified into groups for more convenient handling and management.

Land uses in AGNPS are classified into two categories:

a) Non-cropland

b) Cropland

There is a total of 16 distinct land uses in the study area (Fig. 4). Thirteen of them are "non-cropland uses" and include urban infrastructure, wooded land and other non-cultivated land uses. Annual Rainfall Height, Annual Cover Ratio, Root Mass and Surface Residue Cover were inputted in order to simulate non-cropland uses. Cropland uses consist of croprelated activities such as sowing, harvesting, etc.

Since the study area contains cropland land uses, it is necessary to simulate the effects of agricultural activities such as sowing and harvesting, including their time schedule during a year. The connection of each land use with the above activities was assigned via the input editor and specifically the "Field Data Management" option. Each field data contains one or more events (sowing, harvesting), which are scheduled to take place at a specific time of the year. The time period for each event was determined through the "Management Schedule" option.

\subsection{Soil parameterization}

Four main soil types exist in the study area, whose distribution is illustrated in the map of Fig. 5. The textures of the soil samples obtained from various locations in the basin were identified and categorized per soil type. For each soil type, the average texture was calculated and a specific code number was assigned to each soil type. The average textures, for the four soil types, are quoted in Table 1. Sandy clay loam soils are dominated by sand particles, but contain enough clay to provide structure and fertility. Clay soils have greater strength, especially when they are dry and are susceptible to waterlogging due to poor infiltration and aeration (Melonas, 2004).

Table 1. Average texture of various soil types.

\begin{tabular}{llll}
\hline Soil Type & $\begin{array}{l}\text { Sand } \\
(\%)\end{array}$ & $\begin{array}{l}\text { Clay } \\
(\%)\end{array}$ & $\begin{array}{l}\text { Silt } \\
(\%)\end{array}$ \\
\hline Sandy Clay Loam & 55 & 19 & 26 \\
Silty Loam & 22 & 21 & 57 \\
Loamy Sand & 78 & 4 & 18 \\
Silty Clay Loam & 8 & 39 & 53 \\
\hline
\end{tabular}

Twelve soil hydraulic parameters, such as bulk density, saturated hydraulic conductivity, field capacity and wilting point ratios, out of a total twenty eight parameters included in 
AGNPS, were used to simulate the runoff and sediment transport in the watershed. The values if these parameters for each soil type were derived using the module 'Soil Water Characteristics' of the Soil Plant Atmosphere Water (SPAW) hydrology model, which has been developed by the United States Department of Agriculture (USDA) (Madramootoo \& Norville, 1990). The soil parameters mentioned before were assigned to each soil code number via the input editor. The AGNPS/ArcView interface was then used to assign the soil type to each cell.

\subsection{Discharge and sediment data}

Discharge data at the location of Platanovrisi dam were provided by the Hellenic Public Power Corporation (HPPC/DEI). The mean monthly flow rates at that location for the period 1964-1983 are depicted in Fig. 6, and their average values for the same period in Fig. 7. Discharge measurements at various locations along Nestos river, including location Toxotes (Fig. 1), have been conducted for the interval 1980-1997 by the Greek Ministry of Agriculture. In addition, HPPC/DEI is the only Greek authority which has performed sediment yield measurements, but, unfortunately, these measurements ended in 1983.

\section{5. Meteorological data}

Meteorological (rainfall and climate) data were obtained from two meteorological stations inside the basin (Fig. 8). AGNPS requires detailed meteorological data on a daily basis for the simulation period, stored in a separate file. The meteorological data of the two stations contain eight daily parameters: date, precipitation, daily maximum temperature, daily minimum temperature, dew point temperature, sky cover or solar radiation, wind speed and wind direction. This is the minimum information required to calculate surface runoff and other physical processes, which are simulated by AGNPS.

The two meteorological stations mentioned previously contain monthly rainfall and climate data for the period 1964-2009. Complete sets of data on a daily basis suitable for use by AGNPS exist only for the periods 1980-1990 and 2006-2009. Stochastic time-series of the necessary meteorological parameters at a daily time step for the period 2006 to 2030 were generated with the use of two software packages, namely GlimClim and ClimGen. The data for the period 2006-2009 were used for the calibration of these two software packages. After their calibration, GlimClim was used to estimate daily rainfall values in the study area for the period 2006-2030 and ClimGen was used to estimate the daily values for all the other meteorological parameters for the same period.

Glimclim is a statistical rainfall estimation tool which incorporates the theory of generalized linear models (Generalized Linear Models - GLMs) and allows the quick and reliable generation of stochastic rainfall time series. The software has been developed by Chandler (2002) in collaboration with the Department of Civil Engineering at the Imperial College of London. It can be used to generate time series of data for areas up to $100 \times 100$ $\mathrm{km}^{2}$ (Yang et al., 2005). It has been applied already to the basin of Drama, which is adjacent to the area of the present study (Iordanidis and Anagnostopoulos 2012). That study has confirmed that the model is capable of generating reliable data series in regions with 
Mediterranean climate conditions. The GlimClim package consists of two mathematical models and the simulation software. The first model (Logistic-Events model) is used to generate the rainfall events for the study period, determining whether rainfall will occur or not, on a given day. The second model (Gamma-Magnitude Model) calculates the amount of rainfall in a day for which the Logistic model has determined that rainfall will occur. The parameters of the Logistic and the Gamma model are calibrated using input data from stations within the study area.

A necessary stage before using the data generated by GlimClim is the statistical test of the reliability of the time-series. The verification is implemented by calculating the values of selected statistical measures (such as the maximum and minimum values of monthly rainfall) from the generated data and comparing them with the corresponding values calculated from the recorded data (Iordanidis and Anagnostopoulos, 2012). The set of data for the period 1980-1990, available on a daily basis, was used for the generation of a large number of daily time series of rainfall for the period 1964-2009. For each of these time series, the total monthly rainfall was calculated throughout the period examined. Then, for each simulation, the maximum monthly rainfall value was selected for each of the twelve months, regardless of the year of occurrence. The same procedure was followed for all simulations. Thus, a $n \mathrm{x}$ 12 table was created, were $n$ is the total number of simulations. Each element of the table refers to the maximum monthly rainfall for each simulation. The last step was to determine the maximum value for each column, which yields the maximum monthly rainfall, for the entire time span of the simulation.

The maximum estimated monthly rainfall height at Stations 1 and 2 of Fig. 8 for the period 1964 to 2009 are illustrated in Figs. 9 and 10 respectively. The maximum recorded monthly rainfall height for the period 1964-2008 is also displayed in these diagrams. The simulation values are slightly higher than the recorded data, except from August to October for Station 1 and for August for Station 2. Therefore, the simulation can be considered reliable (Yang et al., 2005).

GlimClim was then used to estimate daily rainfall values in the study area for the period 2006-2030. A large number of simulations (approximately 1000) was conducted for this period. Since GlimClim is a statistical model, the large number of simulations serves in obtaining an adequate sample of estimated values of rainfall for each day in the simulation period. For all simulations, the rainfall for each day in the interval 2006-2009 was compared with the corresponding recorded value. The simulation which yielded daily estimated rainfall closest to the recorded throughout the interval 2006-2009 was selected as the most reliable.

ClimGen is a climate data generation software, which has been developed by the University of Washington in cooperation with the US Department of Agriculture (United States Department of Agriculture - U.S.D.A.). ClimGen uses UED files (Universal Environmental Database) which store daily data for the maximum and minimum temperature, the maximum and minimum relative humidity, dew point temperature, sky cover or solar radiation, wind speed and wind direction. ClimGen employs an algorithm that calibrates the climate generation parameters automatically from the input data. These parameters are then used to generate stochastic time series at a daily step for each of the weather parameters mentioned previously. Similarly to GlimClim, a large number of simulations were conducted for the period 2006-2030. The simulation which yielded daily climate data closest to the 
recorded for the interval 2006-2009 was selected as the most reliable.

\subsection{Model implementation}

In order to calculate runoff, AGNPS uses the Curve Number Method (Xiao, 2003). This method uses the following equation

$$
Q=\frac{\left(W I-0.2 S_{c n}\right)^{2}}{W I+0.8 S_{c n}}, S_{c n}=245\left(\frac{100}{C N}-1\right)
$$

where $Q$ is the surface runoff for each cell, $W I$ the water input (precipitation or irrigation), $S_{c n}$ the retention variable and $C N$ the Curve Number. Hydrologic models are in general sensitive to the values of $C N$ (Kaffas \& Hrissanthou, 2014), which range between 30 and 100. The lower the curve number, the more permeable the soil is. Therefore, lower numbers indicate low runoff potential, whereas larger numbers indicate increased runoff potential. The Curve Number depends on the land use and soil type of each cell, as described by TR-55 (Binger \& Theurer, 2001). Initially, the land use of the corresponding cell is identified, according to the classification of Fig, 4. Considering also the soil type of the cell, the appropriate $C N$ value is selected and the runoff of the cell is evaluated from Eq. (1).

The annual sediment yield, $S_{y},\left(\mathrm{tn} / \mathrm{km}^{2}\right)$ for each cell is calculated by

$$
S_{y}=0.22 Q^{0.68} q_{p}^{0.95} K \cdot L S \cdot C \cdot P
$$

where $q_{p}$ the peak rate of surface runoff and $K, L S, C$ and $P$ are factors of the Revised Universal Soil Loss Equation (RUSLE) (Wischmeier \& Smith 1965).

The most important of these factors is the soil erodibility factor, $K$, which influences the spatial variability of sediment losses. Factor $K$, which is important for the determination of the sensitivity of soil to erosion, the sediment transportability and runoff rate, is directly related to soil properties. Soil texture, structure and particle composition are the main factors affecting soil erodibility. The values of $K$ range typically from about 0.10 to $0.45[(\mathrm{Mg} \mathrm{h} /$ (MJ mm)]. Several formulae have been developed for the determination of $K$ factor (Wang et al., 2016); the most widely used are USLE developed by Wischmeier \& Smith (1978) and EPIC (Erosion Productivity Impact Calculator) developed by Sharpley \&Williams (1990). The former is based on the particle size parameter, the organic matter content, the soil structure code and the soil permeability, whereas the latter requires only the soil particle size distribution and the soil organic carbon content for the determination of $K$ values. Cox and Madramootoo (1998) and Parsakhoo et al. (2014) employed the USLE formula, whereas Liu et al. (2015) favoured the EPIC formula. Similarly to Liu et al. (2015), the erodibility factor in the present study was calculated with the EPIC technique given by Eq. (3):

$$
\begin{aligned}
K= & \left\{0.2+0.3 \exp \left[-0.256 S_{d}\left(1-S_{i} / 100\right)\right]\left[S_{i} /\left(C_{i}+S_{i}\right)\right]\right\}^{0.3} \\
& \left\{1.0-0.25 C_{0} /\left[C_{0}+\exp \left(3.72-2.95 C_{0}\right)\right]\right\}
\end{aligned}
$$

where $S_{d}$ is sand content, $S_{i}$ is silt content, $C_{i}$ is clay content and $C_{0}$ is soil organic carbon content. 
The values of $K$ for the four soil types of the present study, as calculated from the data of Table 1, are listed in Table 2. These values are close to those reported by Liu et al. (2015), which lie in the range between 0.278 and 0.344 . However, serious discrepancies have been reported between estimated and observed values of $K$ factor (Shabani et al. 2014, Ostovari et al. 2016, Wang et al. 2016). Shabani et al. (2014) report that, $K$ is markedly influenced by the content of lime and slope, as well as land use and permeability. EPIC formula, which relies only on sand, silt, clay and soil organic carbon content, does not take into account these factors.

Table 2. Predicted and calibrated $K$ factor values.

\begin{tabular}{|c|c|c|}
\hline Soil Type & $\begin{array}{c}K \\
\text { (predicted) }\end{array}$ & $\begin{array}{c}K \\
\text { (calibrated) }\end{array}$ \\
\hline Sandy Clay Loam & 0.197 & 0.314 \\
\hline Silty Loam & 0.302 & 0.272 \\
\hline Loamy Sand & 0.189 & 0.223 \\
\hline Silty Clay Loam & 0.316 & 0.285 \\
\hline
\end{tabular}

Slope length and steepness factors, $L S$, are topographic factors that indicate the terrain impacts on soil erosion. Slope length, $L$, is defined as the distance from the point of origin of overland flow to the point where the slope decreases sufficiently for deposition to occur. The steepness factor, $S$, is the change in elevation at a specified distance. The terrain slopes in the study area are depicted in Fig. 11. Although various formulae are available for the determination of $L$ and $S$ factors (Wang et al., 2009; Liu et al., 2015), in the present study are evaluated by AGNPS, using the digital elevation model. $L$ and $S$ factors are calculated separately, but it is customary to appear as a combined term.

The vegetation cover and management factor, $C$, represents the effect of both the natural vegetation cover on reducing soil loss in non-agricultural situations, and of cropping and management practices in agricultural activities. Liu et al. (2015) obtained $C$ factor values in terms of the annual averaged vegetation cover, while Wang et al. (2009) and Kuok et al. (2013) report values for various land use types such as forest, grassland and farmland. In the present study the $C$ factor is calculated by the model for all non-water cells in the study area, depending on the land use (cropland or not). For cropland cells AGNPS calculates 24 values of $C$ factor for each year, and an average $C$ factor for each year for non-cropland cells. For cropland land uses, the effects of agricultural activities, such as sowing and harvesting, and their time schedule during a year, are important for the determination of $C$ factor. The effects of agricultural activities and their time schedule during a year, are inputted for each cropland cell, as mentioned previously. 
The conservation support practice factor, $P$, is the ratio of soil loss under a particular conservation support practice, to soil loss for up and down slope cultivation on the unit plot, with no conservation support (Meyer, 1984). Conservation support practices include cropping along the contour, strip-cropping and terracing. Kuok et al. (2013) quote $P$ factor values equal to 0.60 for contouring, 0.35 for strip-cropping and 0.15 for terracing It is evident that the lower the $P$ factor value, the better the practice for controlling soil erosion. Similarly to $C$ factor, $P$ factor is calculated by the model for all non-water cells in the study area. AGNPS calculates sub-factors for contour cropping, strip-cropping and terracing, from which the $P$ factor of the corresponding cell for each year is evaluated.

\section{Calibration and validation}

The calibration and validation of the model are necessary stages prior its use for predictions. In case that the model prediction for runoff and sediment yield at the outlet of the basin over a specified interval agrees closely with measured values, the reliability of the model is confirmed, and no further action is required. In case of discrepancy, the model should be calibrated by adjusting some of its parameters, in a way that the difference between predicted and measured values is minimized. Next, the model should be validated for a different period, in order to check the validity of these adjustments.

Year 1980 was selected for the initial check and the possible calibration of the model if necessary. Measured values of the discharge from Nestos river into the basin and of the runoff and sediment yield at the outlet of the basin (location Toxotes) were available for this year, together with daily meteorological data. In addition, the mean annual discharge of the dam was almost the same for both years, equal to $46 \mathrm{~m}^{3} / \mathrm{s}$.

The results of the simulation obtained for $K$ factor values predicted from EPIC formula are listed in Table 3. These results contain the simulated values of mean annual runoff and the sediment yield for the year 1980 at the location Toxotes. The corresponding measured values are also listed. We see that the values of both the runoff and the sediment yield obtained from the simulation are lower than the measured, by $7.58 \%$ and $17.85 \%$ respectively.

Table 3. Runoff and sediment yield for year 1980. $K$ values predicted from EPIC formula.

\begin{tabular}{lccc}
\hline & $\begin{array}{c}\text { Measured } \\
\text { values }\end{array}$ & $\begin{array}{c}\text { Simulated } \\
\text { values }\end{array}$ & Deviation \\
\hline Runoff $\left(\mathrm{m}^{3} / \mathrm{s}\right)$ & 48.66 & 45.23 & $7.58 \%$ \\
Sediment Yield $(t n / y r)$ & 298,000 & 244,781 & $17.85 \%$ \\
\hline
\end{tabular}

The discrepancy, especially for the sediment yield, although can be considered within acceptable limits (Liu et al., 2015) is rather large. The parameter most responsible for this discrepancy was considered to be the $K$ factor, since, as previously stated, its predicted values are rather approximate. Preliminary tests were conducted, to investigate the impact of $K$ 
factor of each of the four soil types of the study area on runoff and sediment yield. This was implemented by modifying the $K$ factor value of one of the soil types, keeping the values of the other three soil types constant. It was found that the results, especially of sediment yield, were susceptible even to small changes of $K$ factor values, especially for Sandy Clay Loam. Since the value of $K$ for Sandy Clay Loam obtained from EPIC formula yielded underestimated results, it was considered reasonable to test larger $K$ values.

A very large number of tests was conducted, for the determination of the $K$ factor values, which yielded values of mean annual runoff and sediment yield for the year 1980 as close as possible to the measured values. These values, denoted as "calibrated", are listed in the right column of Table 2. With the exception of Sandy Clay Loam, whose calibrated $K$ value was significantly higher than the predicted, the calibrated $K$ values of the other three soil types were rather close to the predicted from EPIC formula. The calibrated values of Silty Loam and Silty Clay Loam were by $10 \%$ lower than the predicted, whereas the calibrated value of Loamy Sand was by $15 \%$ higher than the predicted.

The results of mean annual runoff and sediment yield at the location Toxotes using the calibrated $K$ values are listed in Table 4, together with the corresponding measured values. The simulated runoff value is now 5.24\% lower than the predicted and the simulated sediment yield $2.21 \%$ lower than the predicted.

Table 4. Runoff and sediment yield for 1980, using calibrated $K$ factor values.

\begin{tabular}{llll}
\hline & $\begin{array}{c}\text { Measured } \\
\text { values }\end{array}$ & $\begin{array}{c}\text { Simulated } \\
\text { values }\end{array}$ & Deviation \\
\hline Runoff $\left(\mathrm{m}^{3} / \mathrm{s}\right)$ & 48.66 & 47.58 & $5.24 \%$ \\
Sediment Yield $(t n / y r)$ & 298,000 & 282,364 & $2.21 \%$ \\
\hline
\end{tabular}

A necessary step before using AGNPS as prediction tool in the study area was its validation. In case that the evaluated values of runoff and sediment yield at the location Toxotes in a year different from 1980 were close to the measured, the model is considered as validated. Year 1981 was selected for the validation, using the calibrated $K$ factor values. The inflow in the basin and the available climate and rainfall data for 1981 were used for the validation. The mean annual inflow from Nestos river was almost the same for both years, very close to $46 \mathrm{~m}^{3} / \mathrm{s}$. The results are listed in Table 5 . It is evident that the simulated values of both runoff and sediment yield agree closely with the measured, which confirms the reliability of calibrated $K$ values. It should be noted that a similar simulation for 1981 using the predicted values of $K$ yielded runoff and sediment yield lower than the measured by $9 \%$ and $20 \%$ respectively. 
Table 5. Runoff and sediment yield for 1981, using calibrated $K$ factor values.

\begin{tabular}{llll}
\hline & $\begin{array}{c}\text { Measured } \\
\text { values }\end{array}$ & $\begin{array}{c}\text { Simulated } \\
\text { values }\end{array}$ & Deviation \\
\hline $\operatorname{Runoff}\left(\mathrm{m}^{3} / \mathrm{s}\right)$ & 54.10 & 53.21 & $1.58 \%$ \\
Sediment Yield $(t n / y r)$ & 497,000 & 515,476 & $3.72 \%$ \\
\hline
\end{tabular}

\section{Application, results and discussion}

Two different simulations were performed using AGNPS, one for the period 1980-1990 and the other for 2006-2030. The purpose of both simulations was the estimation of the sediment yield at the outlet of the river Nestos basin at the location Toxotes.

The period 1980-1990 was selected, because detailed meteorological data on a daily basis were available from the two meteorological stations within the basin. Although no measured values of sediment yield were available after 1983, estimated values were provided by Hrissanthou (2002) at the same location and period of time. Table 6 presents the estimated values of sediment yield using the AGNPS model in comparison with the results of two different simulation models by Hrissanthou (2002). The sediment yield, in Table 7 is the year average for the whole period of eleven years.

Table 6. Estimated values of sediment yield $(t n / y r)$

\begin{tabular}{cccc}
\hline & & \multicolumn{2}{c}{ Hrissanthou (2002) } \\
Year & AGNPS & Model 1 & Model 2 \\
\hline 1980 & 282,355 & 298,000 & 278,000 \\
1981 & 515,476 & 528,000 & 588,000 \\
1982 & 467,195 & 446,000 & 426,000 \\
1983 & 105,124 & 80,000 & 73,000 \\
1984 & 295,626 & 492,000 & 494,000 \\
1985 & 170,985 & 119,000 & 131,000 \\
1986 & 256,752 & 196,000 & 198,000 \\
1987 & 511,482 & 638,000 & 673,000 \\
1988 & 350,203 & 396,000 & 383,000 \\
1989 & 213,839 & 201,000 & 207,000 \\
1990 & 162,335 & 75,000 & 64.000 \\
\hline
\end{tabular}


Table 7. Estimated values of mean annual sediment yield for years 1980-1990.

\begin{tabular}{cccc} 
Technique & AGNPS & \multicolumn{2}{c}{ Hrissanthou (2002) } \\
& & Model 1 & Model 2 \\
\hline Sediment Yield $(t n / y r)$ & 302,852 & 315,500 & 319,500 \\
\hline
\end{tabular}

Considerable agreement of the results of the two studies is observed for years 1980-1982 and for years 1988-1989. The greatest proportional discrepancy is observed for years 1984, 1987 and 1990. However, in spite of the differences detected in individual years, the values of mean annual sediment yield for the whole period derived from the present study and the two models by Hrissanthou are very close.

Another simulation was conducted for the years 2006-2030, after the dam of Platanovrisi was constructed. The inflow of water in the study area was different from that depicted in Figs. 6 and 7, since it was regulated by the dam operation. A constant inflow of $6 \mathrm{~m}^{3} / \mathrm{s}$ was assumed for the whole period. Although this value is rather arbitrary, preliminary tests revealed that the inflow has small effect on the results. The rainfall and climate data for this interval were generated by GlimClim and ClimGen respectively, using existing data for the period 2006-2009. All other parameters were the same as for the simulation for years 19801990. The estimated sediment yield for each year is displayed in Fig. 12. The sediment yield fluctuates from 50,000 th (year 2025) to 600,000 th (year 2016). These fluctuations are analogous to those for the period 1980-1990 (Table 6). The trend line plotted in Fig. 12 shows a tendency for reduction of sediment yield from approximately 300,000 th in the beginning of the period to 200,000 th at the end of the period. Interestingly, approximately $300,000 \mathrm{tn}$ is the mean annual sediment yield for the period 1980-1990. Table 8 presents the estimated values of mean annual runoff and sediment yield at location Toxotes for the years 2006-2030. The mean annual runoff is by 5\% lower than that for the period 1980-1990, and the mean annual sediment yield lower by $20 \%$. This is in agreement to the study by Liu et al. (2015), according to which, the decrease of runoff from 1989 to 1998 at Beibei Station, in spite of annual fluctuations, is associated with a decrease in the sediment load. The same trend between sediment transport rate and discharge was observed by Metallinos \& Hrissanthou (2010) in Nestos river, Greece.

Table 8. Estimated values of mean annual runoff and sediment yield (Years 2006-2030)

\begin{tabular}{lc}
\hline $\operatorname{Runoff}\left(\mathrm{m}^{3} / \mathrm{s}\right)$ & 44.3 \\
Sediment Yield $(\mathrm{tn} / \mathrm{yr})$ & 252,266 \\
\hline
\end{tabular}

Table 9 presents a comparison of mean annual sediment yield rates for Nestos River with related references (Zarris et al., 2011). All sediment yield estimates are of the same order of magnitude. The inconsistency between sediment yield and catchment area can be justified 
from the different data and techniques employed by various researchers. Even for the same catchment area (River Mouth) the difference of sediment yield quoted by the two relevant studies is of the order $100 \%$. In any case, the sediment yield derived from the present study, and the sediment yield obtained by the two models of Hrissanthou (2002), are higher than the values reported in the other studies.

Table 9. Comparison of mean annual sediment yield rates for Nestos River.

References

Gauging station/

Catchment area $\left(\mathrm{km}^{2}\right)$

Mean annual sediment yield $\left(\mathrm{tn} / \mathrm{km}^{2}\right)$

\begin{tabular}{llc}
\hline $\begin{array}{l}\text { Gergov (1996) } \\
\text { Gergov and }\end{array}$ & M. Kula (Bulgaria)/1511 & 202.0 \\
$\begin{array}{l}\text { Karagiozova (2002) } \\
\text { Paraskevopoulos and } \\
\text { Georgiadis (2001) }\end{array}$ & Hadgidumovo (Bulgaria)/2123 & 125.0 \\
$\begin{array}{l}\text { Paraskevopoulos and } \\
\text { Georgiadis (2001) }\end{array}$ & Greek-Bulgarian Border/3584 & 181.0 \\
UNEP/MAP (2003) & River Mouth $($ Greece)/6365 & 78.0 \\
$\begin{array}{l}\text { Poulos and } \\
\text { Alexandrakis (2005) }\end{array}$ & River Mouth $($ Greece)/6100 & 160.0 \\
$\begin{array}{l}\text { Zarris, Vlastara and Panagoulia } \\
\text { (2011) }\end{array}$ & Temenos $($ Greece)/4394 & 157.4 \\
$\begin{array}{l}\text { Hrissanthou - Mod. 1 (2002) } \\
\text { Hrissanthou - Mod. 2 (2002) }\end{array}$ & Toxotes $($ Greece)/838 & 203.4 \\
This study (1980-1990) & Toxotes $($ Greece)/838 & 376.5 \\
This study (2006-2030) & Toxotes $($ Greece)/884 & 381.3 \\
\hline
\end{tabular}

\section{Conclusions}

The AGNPS software was employed in order to simulate both runoff and sediment yield in the basin of Nestos River, downstream of the hydroelectric dam of Platanovrisi. After the calibration and validation of AGNPS two different simulations were conducted, one for the period 1980-1990 and another for the period 2006-2030, after the construction of the dam in 1998. For the former of these simulations (1980-1990) existing meteorological data at a daily basis were employed. The mean annual sediment yield for the period 1980-1990 was very close to that obtained at the same location by Hrissanthou (2002), in spite of differences detected at specific years. Apparently, the good agreement of the mean annual sediment yield acts to reinforce the validity of the present model. The simulation for the period 2006-2030, the necessary climate and rainfall data for which were obtained using the GlimClim and 
ClimGen software packages, yielded reduced value of the mean runoff by $5 \%$ and reduced value of the mean annual sediment yield by $20 \%$, compared to the corresponding values for the period 1980-1990. This constitutes strong evidence, that the runoff play a key role for the sediment yield in the area. 


\section{Declarations}

Funding: No funding was received by the authors for this research

Conflicts of interest/Competing interests: The authors declare that they have no conflict of interest

Availability of data and material: The data that support the findings of this study are available from the corresponding author on request.

Authors' contributions: All authors, George Paschalidis, Ilias Iordanidis and Petros Anagnostopoulos contributed to the study conception and implementation. The first draft of the manuscript was written by Petros Anagnostopoulos and all authors read and approved the final manuscript. 


\section{References}

Beasley, D. B., Huggins, L. F., \& Monke, E. J. (1980). Answers: a model for watershed planning. Transactions of American Society of Agricultural Engineering, 23(4), 938-944.

Binger, R. C., Mutchler, C. K., \& Murphee, C. E. (1992). Predictive capabilities of erosion models for different storm sizes. Transactions of American Society of Agricultural Engineering, 35(2), 505-513.

Binger, R. L., Darden, R., Herring, G. J., \& Martz, L. W. (1998). Topagnps user manual. TR55. USDA-ARS. United States Department of Agriculture, Agricultural Research Service (USDA-ARS), Washington D.C.

Binger, R. L., \& Theurer, F. D. (2001). AGNPS98: A suite of water quality models for watershed use. Proceedings of the Sediment Monitoring, Modeling, and Managing, Seventh Federal Interagency Sedimentation Conference, Reno, NV, USA, 25-29.

Chandler, R. (2002). GLIMCLIM: Generalized linear modelling for daily climate time series (software and user guide), Tech. Rep. 227, Dept. of Stat. Sci., UCL, London.

Cox, C. A., \& Madramootoo, C. A. (1998). Application of geographic information systems in watershed management planning in St Lucia. Computers and Electronics in Agriculture, 20, 229-250.

De Roo, A. P. J. (1998). Modelling runoff and sediment transport in catchments using GIS. Hydrological Processes, 12(6), 905-922.

Dendy, F. E., \& Boltan, G. C. (1976). Sediment yield-runoff drainage area relationships in the United States. J Soil Water Conserv, 31(6), 264-266.

Gergov, G. (1996). Suspended sediment load of Bulgarian rivers. GeoJournal, 40(4), 387396.

Gergov, G., \& Karagiozova, T. (2002). Sediment load of Bulgarian Rivers. National Institute of Meteorology and Hydrology, Sofia.

Hrissanthou, V. (2002). Comparative application of two erosion models to a basin. Hydrological Sciences, 47(2), 279-292.

Iordanidis, I. (2010). Investigation of nitrate pollution in a river basin from rural activities. Ph.D. Thesis, University of Thessaloniki, Department of Civil Engineering, Thessaloniki, Greece (in Greek).

Iordanidis, I., \& Anagnostopoulos, P. (2012). Control of reliability of a generalized linear model for the generation of stochastic rainfall series. Hydrotechnica, Journal of the Hellenic Hydrotechnical Association, 21, available from web (in Greek).

Kaffas, K., \& Hrissanthou, V. (2014). Application of a continuous rainfall-runoff model to the basin of Kosynthos river using the hydrologic software HEC-HMS. Global NEST Journal, 16(1), 188-203.

Kaffas, K., \& Hrissanthou, V. (2015). Estimate of Continuous Sediment Graphs in a Basin, using a Composite Mathematical Model. Environmental Processes, 2(2), 361-378.

Knisel, W. G. (1980). CREAMS: a field-scale model for chemicals, runoff, and erosion from agricultural management systems. USDA-SEA Conservation Research Report No. 26, Washington D.C.

Kuok,K. K. K., Mah, D. Y. S., \& Chiu, P. C. (2013). Evaluation of C and P Factors in Universal Soil Loss Equation on Trapping Sediment: Case Study of Santubong River. Journal of Water Resource and Protection, 5, 1149-1154.

Laflen, J. M., Lane, L. J., \& Foster, G. R. (1991). WEPP: a new generation of erosion prediction technology. J Soil Water Conserv, 46(1), 34-38. 
Liu, X., Qi, S., Huang, Y., Chen, Y., \& Du, P. (2015). Predictive modeling in sediment transportation across multiple spatial scales in the Jialing River Basin of China. International Journal of Sediment Research, 30, 250-255.

Madramootoo, C. A., \& Norville, P. O. (1990). Rainfall-runoff erosivity factors for the Eastern Caribbean islands of Barbados and St Lucia. American Society of Agricultural Engineering, 6(2), 161-163.

Melonas, J. (2004). A citizen's guide to erosion and Sediment control in Maryland. The Chesapeake Bay Foundation, 29(8), 158-159.

Merritt, W. S., Letcher, R. A., \& Jakeman, A. J. (2003). A review of erosion and sediment transport models. Environ Model Softw, 18, 761-799.

Metallinos, A., \& Hrissanthou, V. (2010). Regression relationships between sediment yield and hydraulic and rainfall characteristics for two basins in northeastern Greece. Proceedings 6th International Symposium on Environmental Hydraulics, Athens, 899904.

Meyer, D. (1984). Evolution of the universal soil loss equation. Journal of Soil and Water Conservation, 39(2), 99-104.

Morgan, R. P. C., Quinton, J. N., Smith, R. E., Govers, G., Poesen, J. W. A., Auerswald, K., Chisci, G., Torri, D., \& Styczen, M. (1998). The European Soil Erosion Model EUROSEM: a dynamic approach for predicting sediment transport from fields and small catchments. Earth Surf Process, 23, 527-544.

Musgrave, G. W. (1947). The quantitative evaluation of factors in water erosion, a first approximation. J Soil Water Conserv 2(3), 133-138.

Natural Resources Conservation Service (NRCS) (2001). AnnAGNPS Version 1: User Documentation., United States Department of Agriculture, Agricultural Research Service (USDA-ARS), National Sedimentation Laboratory, Washington D.C.

Ostovari, Y., Ghorbani-Dashtaki, S., Bahrami, H.-A., Naderi M., Dematte, J. A. M., \& Kerry, R. (2016). Modification of the USLE K factor for soil erodibility assessment on calcareous soils in Iran. Geomorphology, 273, 385-395.

Paraskevopoulos, D., \& Georgiadis, N. (2001). Pilot study for the assessment of water bodies as heavily modified case study the Nestos River. Public Power Corporation, Directory for the Development of Hydraulic Works, p 12, Athens, (in Greek).

Parsakhoo, A., Lotfalian, M., Kavian, A., \& Hosseini, S. A. (2014). Prediction of the soil erosion in a forest and sediment yield from road network through GIS and SEDMODL. International Journal of Sediment Research, 29, 118-125.

Poulos, S., \& Alexandrakis, G. (2005). Seasonal fluctuation of the sediments (in suspension) yield of parts of Greek river catchments and its relation to the corresponding values of water yield. Seventh National. Hydrogeol. Conf. Hellenic Hydrogeol. Soc., 437-444, 5-6 October 2005, Athens, Greece (in Greek with English abstract).

Renard, K. G., Foster, G. R., Weesies, G. A., McCool, D. K., \& Yoder, D. C. (1997). Predicting soil erosion by water - a guide to conservation planning with the Revised Universal Soil Loss Equation (RUSLE). United States Department of Agriculture, Agricultural Research Service (USDA-ARS), Handbook No. 703. USA Government Printing Office, Washington D.C.

Renfro, G. W. (1975). Use of erosion equations and sediment delivery rations for predicting sediment yield. In: Present and prospective technology for predicting sediment yields and sources. United States Department of Agriculture, Agriculture Research Service (USDAARS-S-40), 33-45, Washington D.C.

Schulze, R. E. (1995). Hydrology and agrohydrology: a text to accompany the ACRU 3.0 agrohydrological modelling system. Water Research Commission, Report TT69/95, Pretoria, RSA. 
Shabani, F., Kumar, L., \& Esmaeili, A. (2014). Improvement to the prediction of the USLE K factor. Geomorphology, 204, 229-234.

Sharma, T. C., \& Dickinson, W. T. (1979). Discrete dynamic model of watershed sediment yield. ASCE J Hydraul Div, 105(5), 555-571.

Sharpley, A. N., \& Williams, J. R. (1990). EPIC Erosion/Productivity Impact Calculator: 1. Model Documentation. United States Department of Agriculture, Technical Bulletin No. 1768, USA Government Printing Office, Washington D.C.

UNEP/MAP (2003). Riverine transport of water, sediments and pollutants to the Mediterranean Sea. UNEP/Mediterranean Action Plan, Athens.

Van Remortel, R., Hamilton, M., \& Hickey, R. (2001). Estimating the LS factor for RUSLE through iterative slope length processing of digital elevation data. Cartography, 30, 2735.

Wang, G., Hapuarachchi, P., Ishidaira, H., Kiem, A. S., \& Takeuchi, K. (2009). Estimation of soil erosion and sediment yield during individual rainstorms at catchment scale. Water Resouces Management, 23, 1447-1465.

Wang, B., Zheng, F., \& Guan, Y. (2016). Improved USLE-K factor prediction: A case study on water erosion areas in China. International Soil and Water Conservation Research, 4, $168-176$.

Williams, J. R., \& Hann, R.W. Jr (1978). Optimal operation of large agricultural watersheds with water quality constraints. Texas Water Resources Research Institute, Texas A\&M University, Tech. Rept. No. 96.

Wischmeier, W. H., \& Smith, D. D. (1965). Predicting rainfall erosion losses from cropland east of the Rocky Mountains. United States Department of Agriculture, Agriculture Handbook No. 282. USA Government Printing Office, Washington D.C.

Wischmeier, W. H., \& Smith, D. D. (1978). Predicting rainfall erosion losses: A guide to conservation planning. United States Department of Agriculture, Agriculture Handbook No. 537, USA Government Printing Office, Washington D.C.

Xiao, H. (2003). An integrated GIS-AnnAGNPS modeling interface for non-point source pollution assessment. Proceedings of the $3^{\text {rd }}$ Annual ESRI international GIS user conference, San Diego, CA, USA July 7-11.

Yang, C., Chandler, R., Ishama, V. S., Antonia, C., \& Wheater, H. S. (2005). Simulation and downscaling models for potential evaporation. Journal of Hydrology, 302, 239-254.

Zarris, D., Vlastara, M., \& Panagoulia, D. (2011). Sediment delivery assessment for a Transboundary Mediterranean Catchment: The example of Nestos river catchment. Water Resources Management, 25, 3785-3803. 


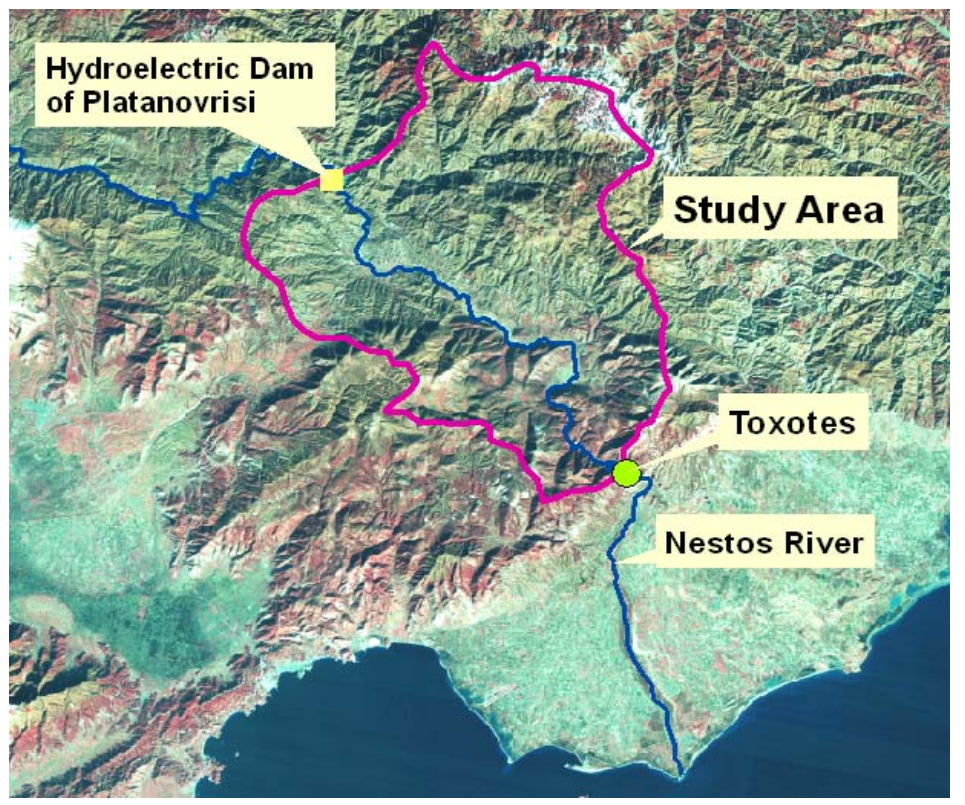

Fig 1 . The study area. 


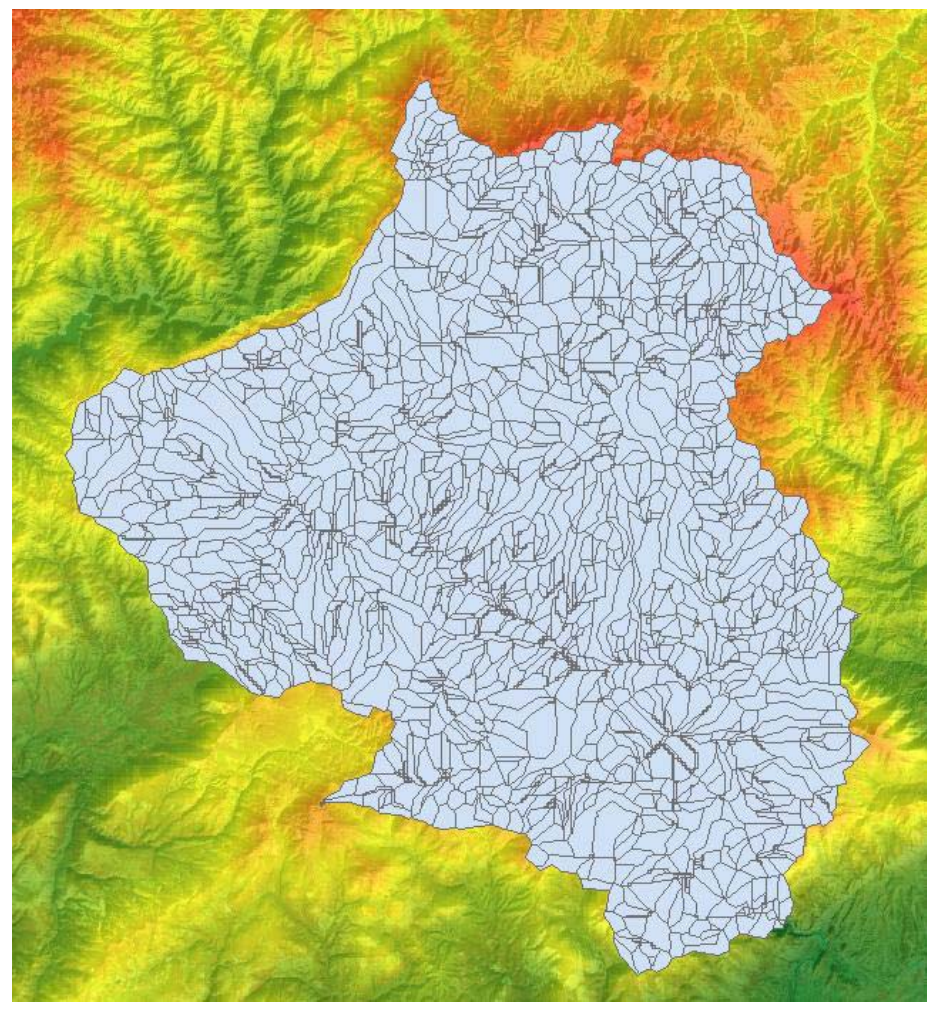

Fig 2. Area discretisation into 1568 amorphous cells. 


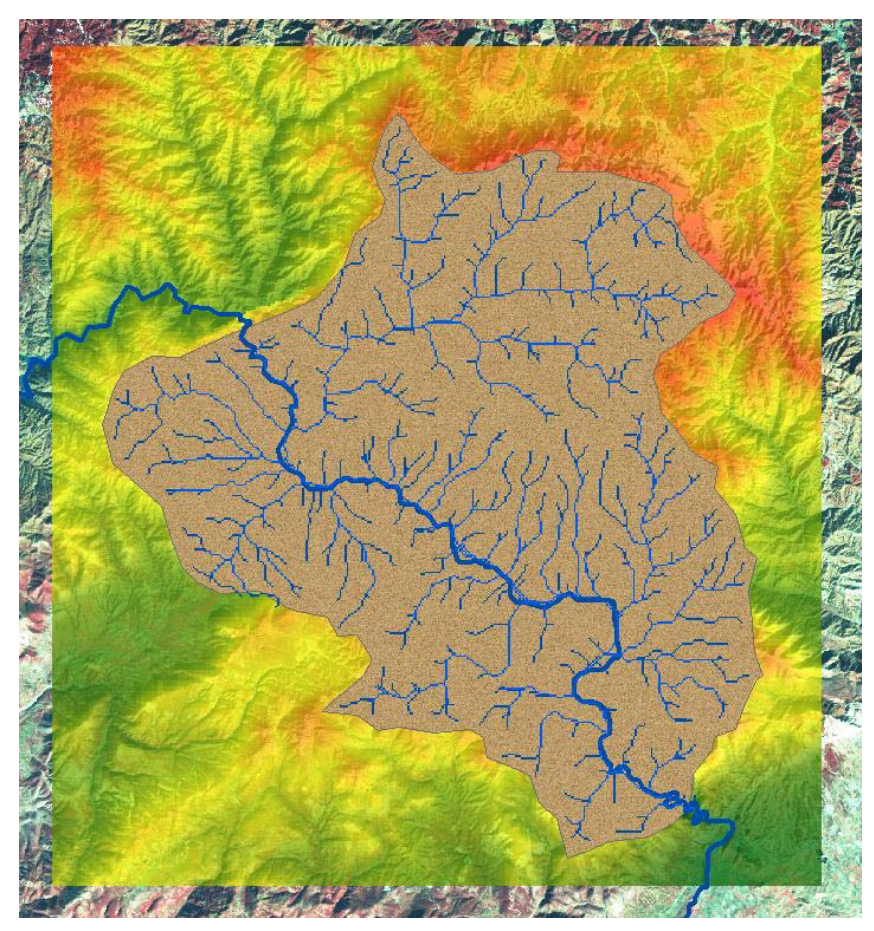

Fig 3. The drainage network of the study area (699 channel reaches). 


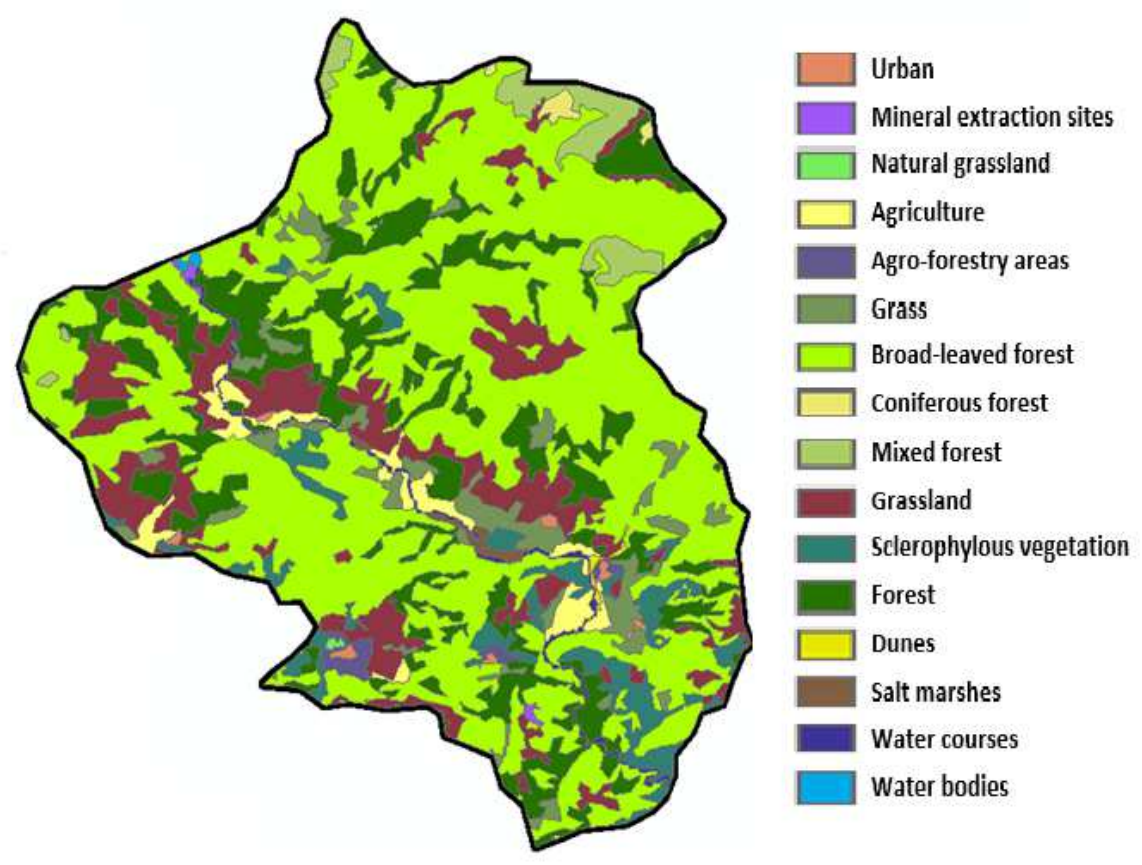

Fig 4. The land uses of the study area. 


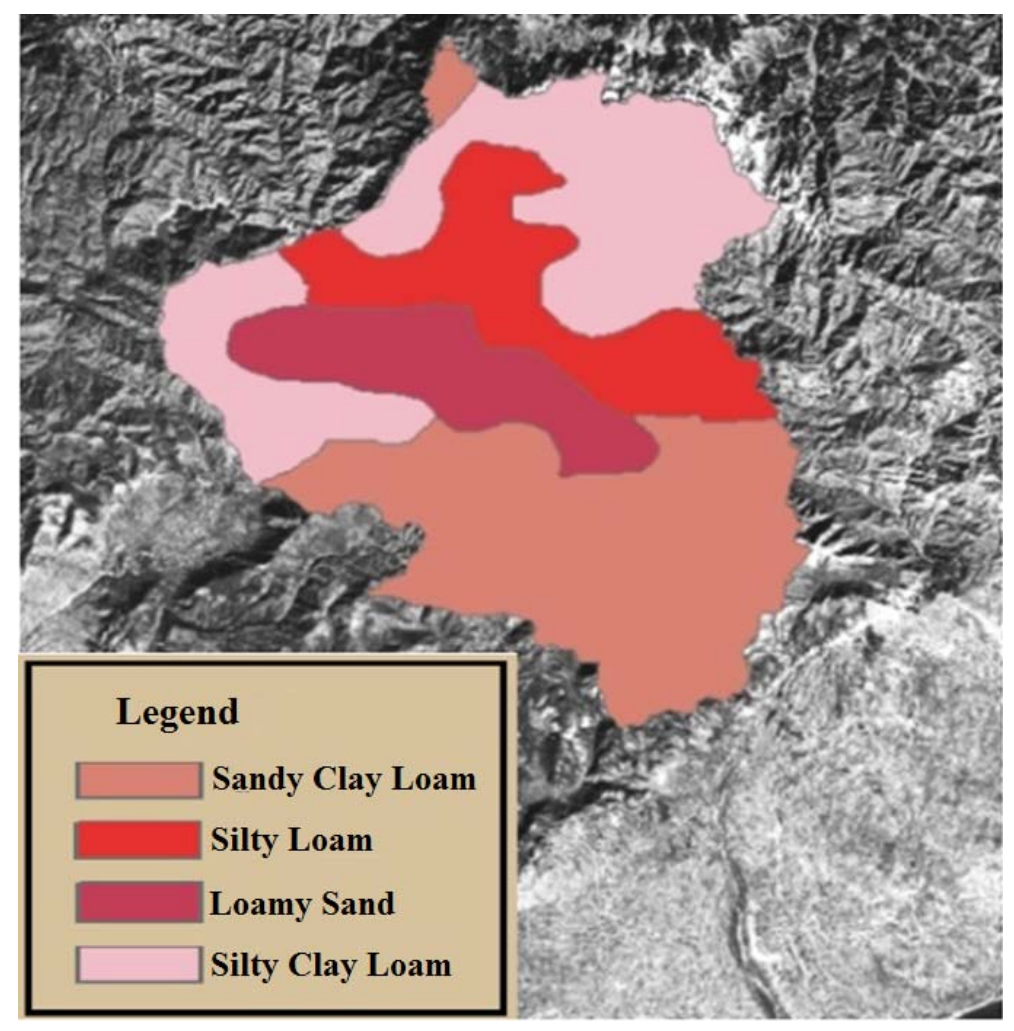

Fig. 5. Soil map of the study area. 


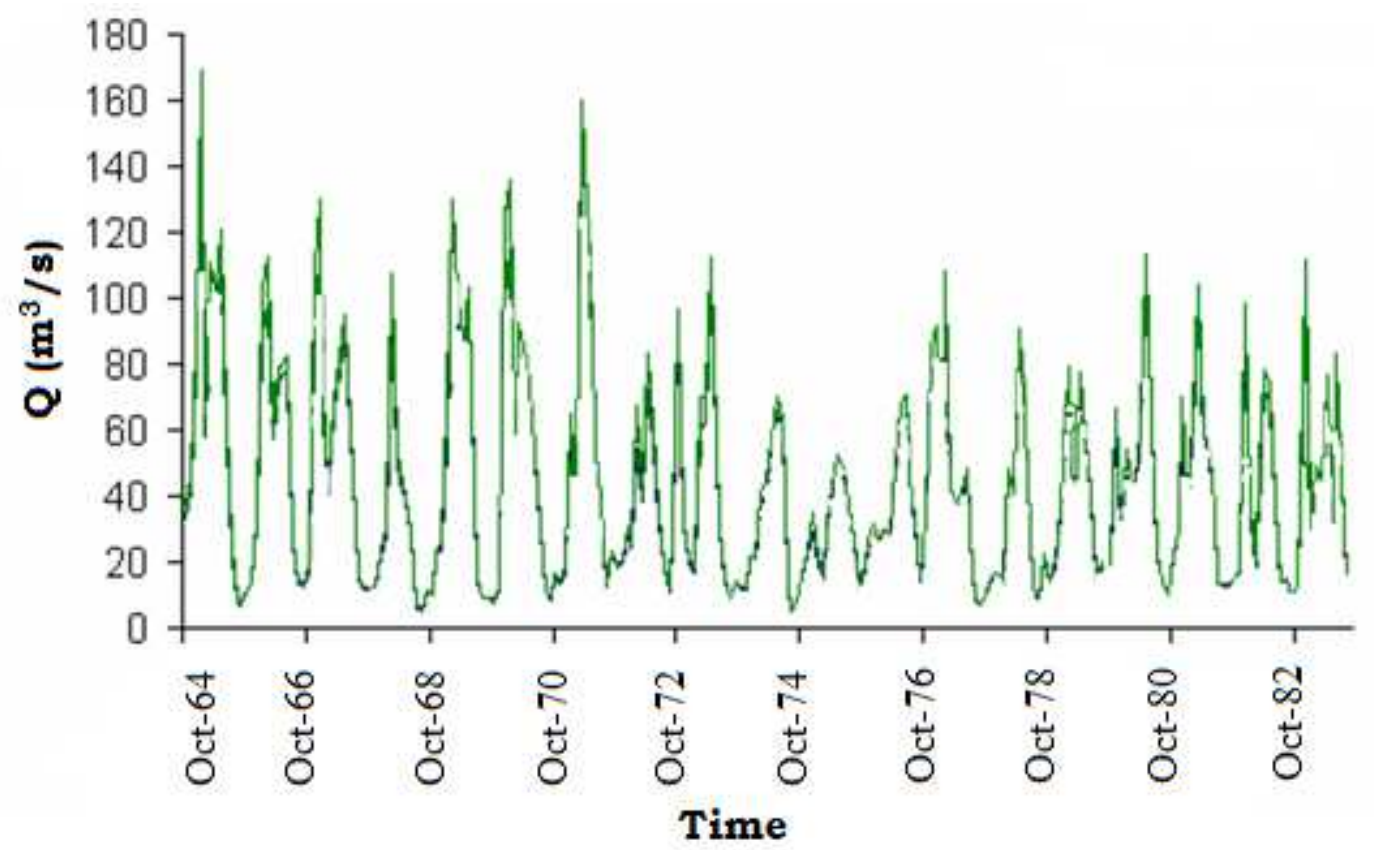

Fig.6. Mean monthly flow rate at Platanovrisi dam for the period 1964-1983. 


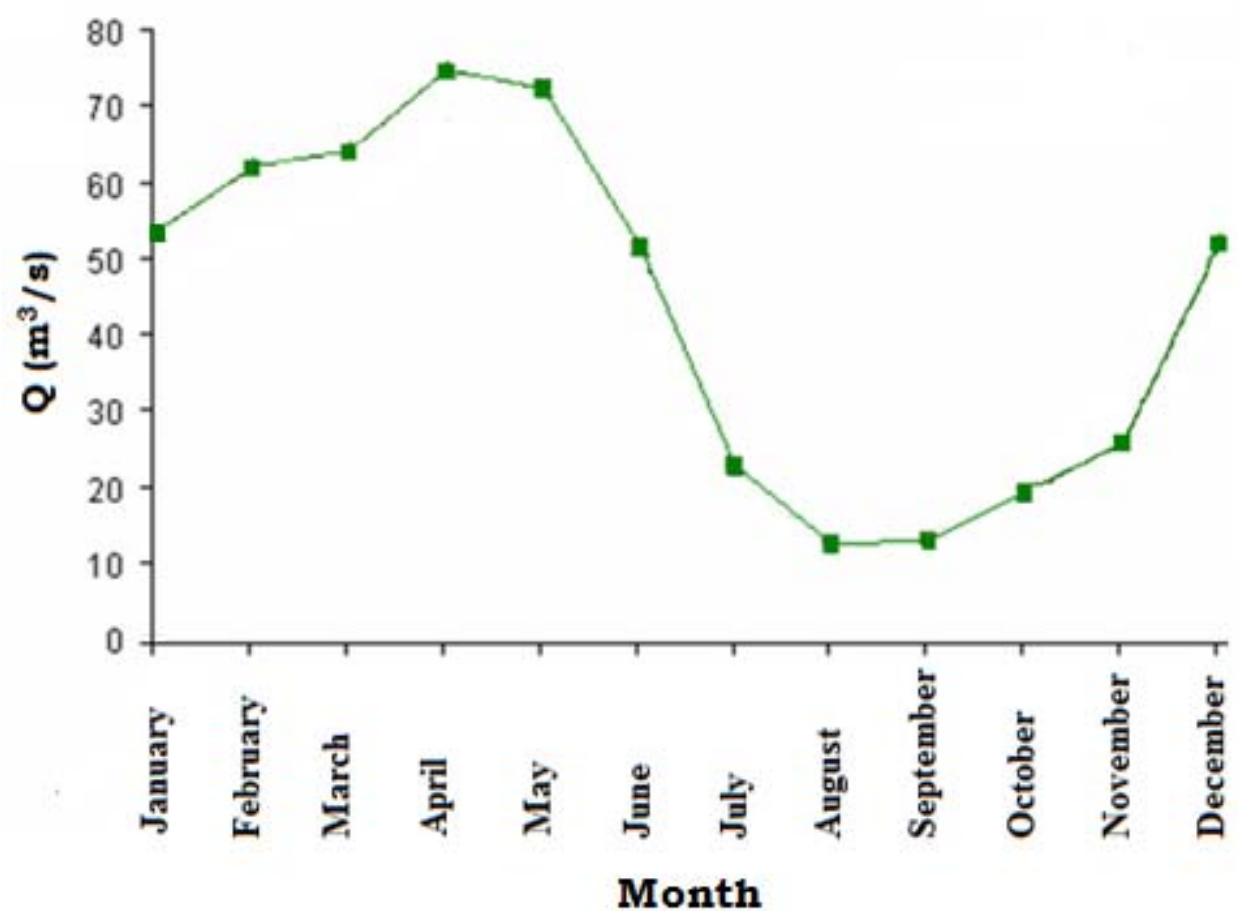

Fig. 7. Average mean monthly flow rate at Platanovrisi dam for the period 1964-1983. 


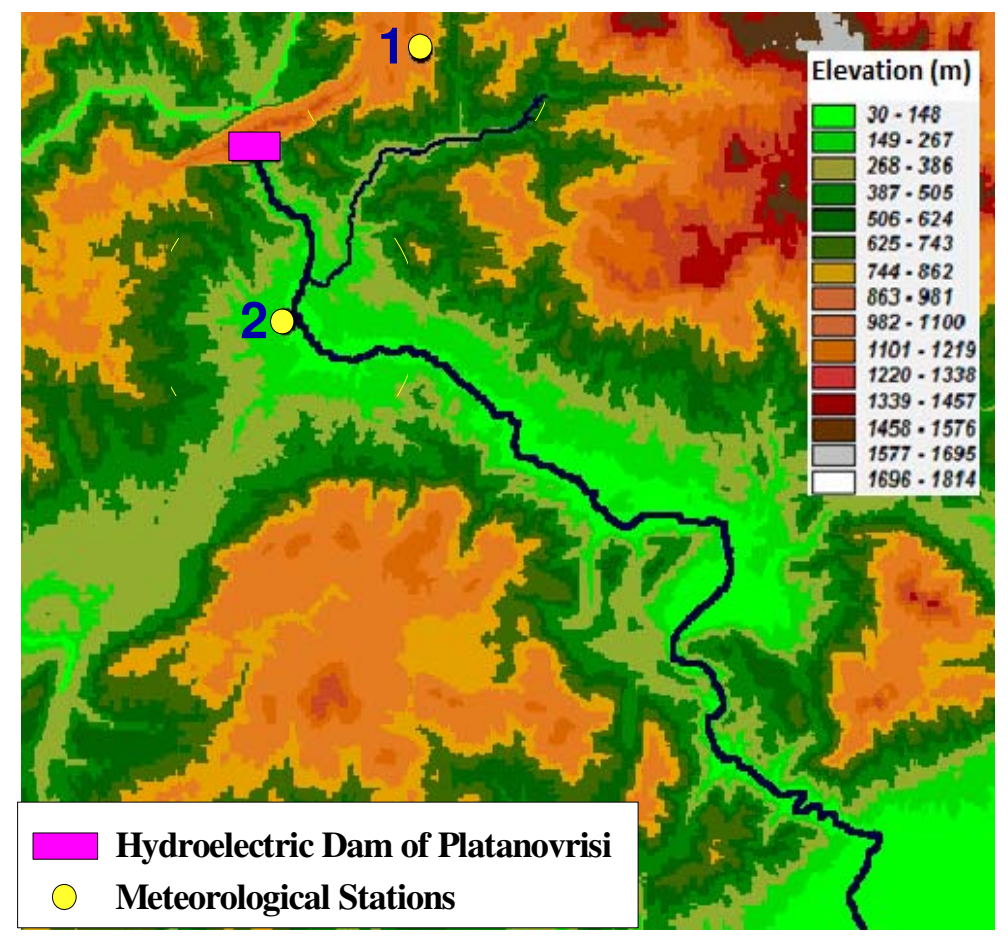

Fig 8 . The study area with the two meteorological stations. 


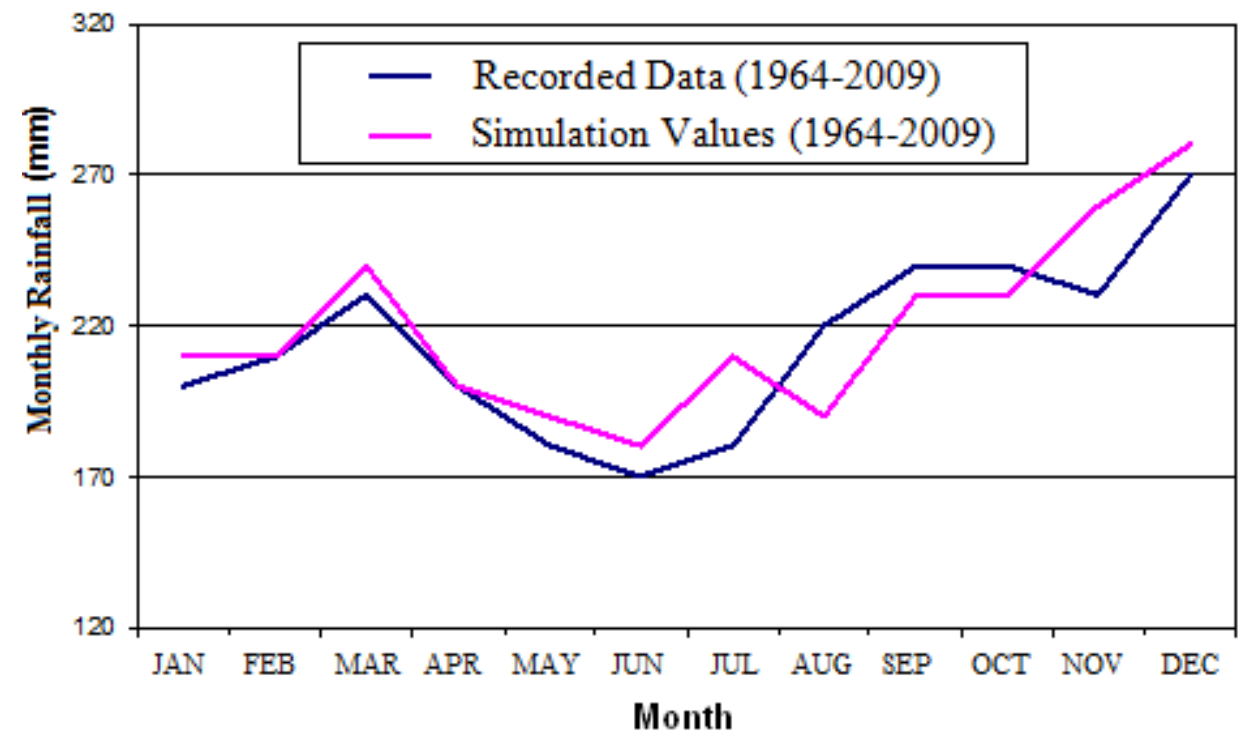

Fig 9. Maximum monthly rainfall at station 1. 


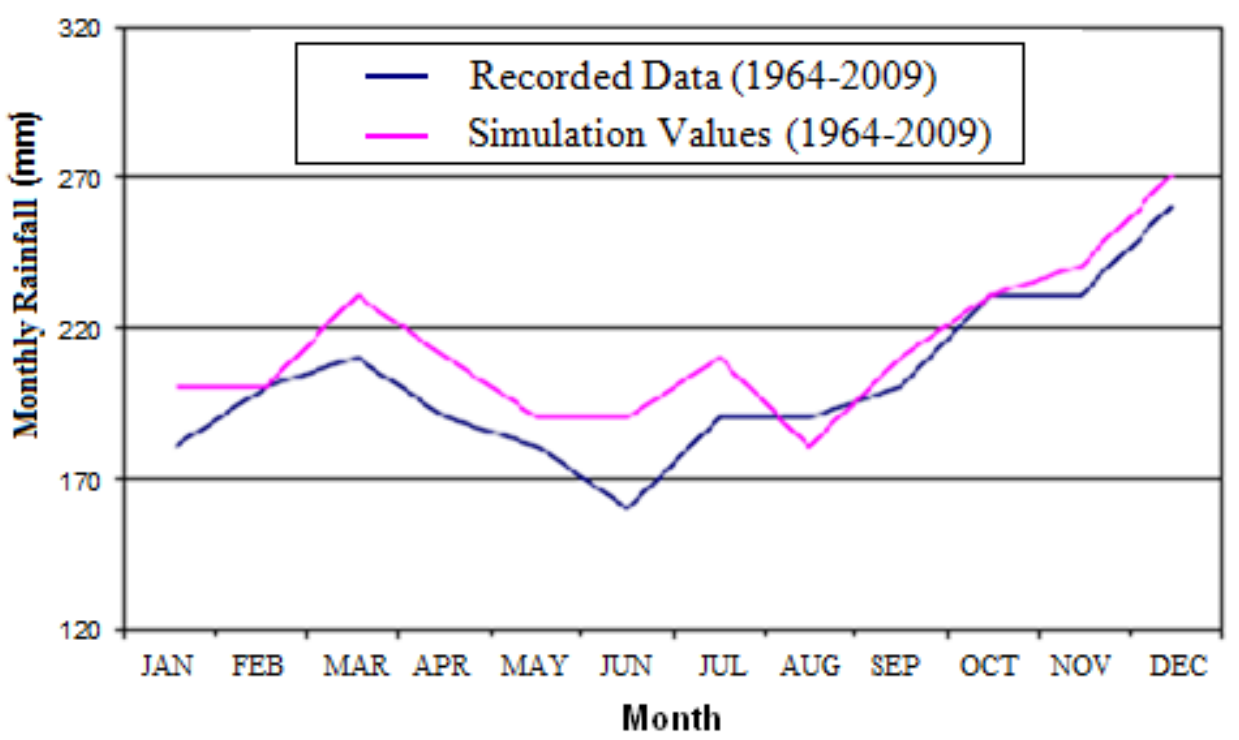

Fig 10. Maximum monthly rainfall at station 2. 


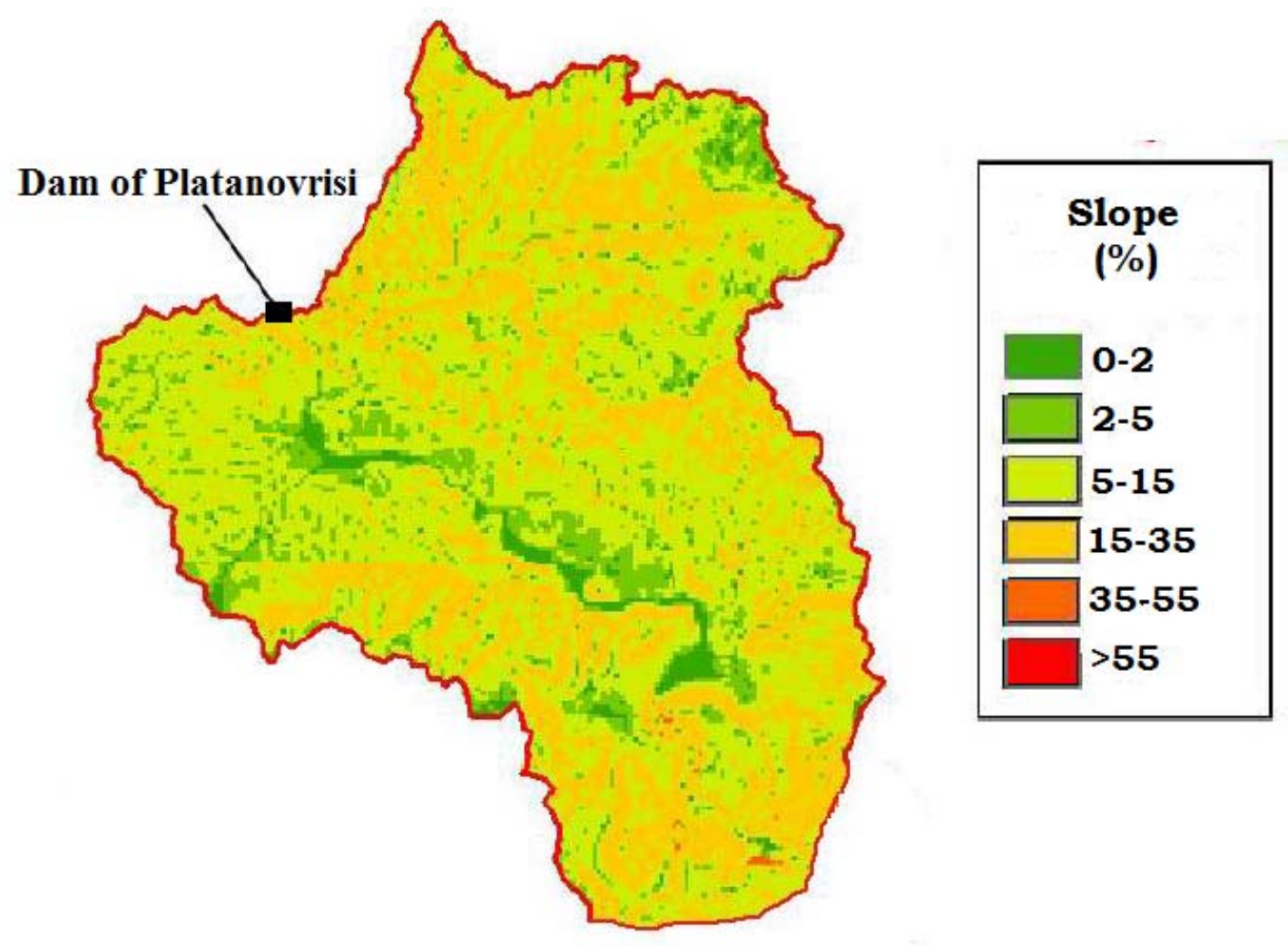

Fig. 11. Terrain slopes in the study area. 


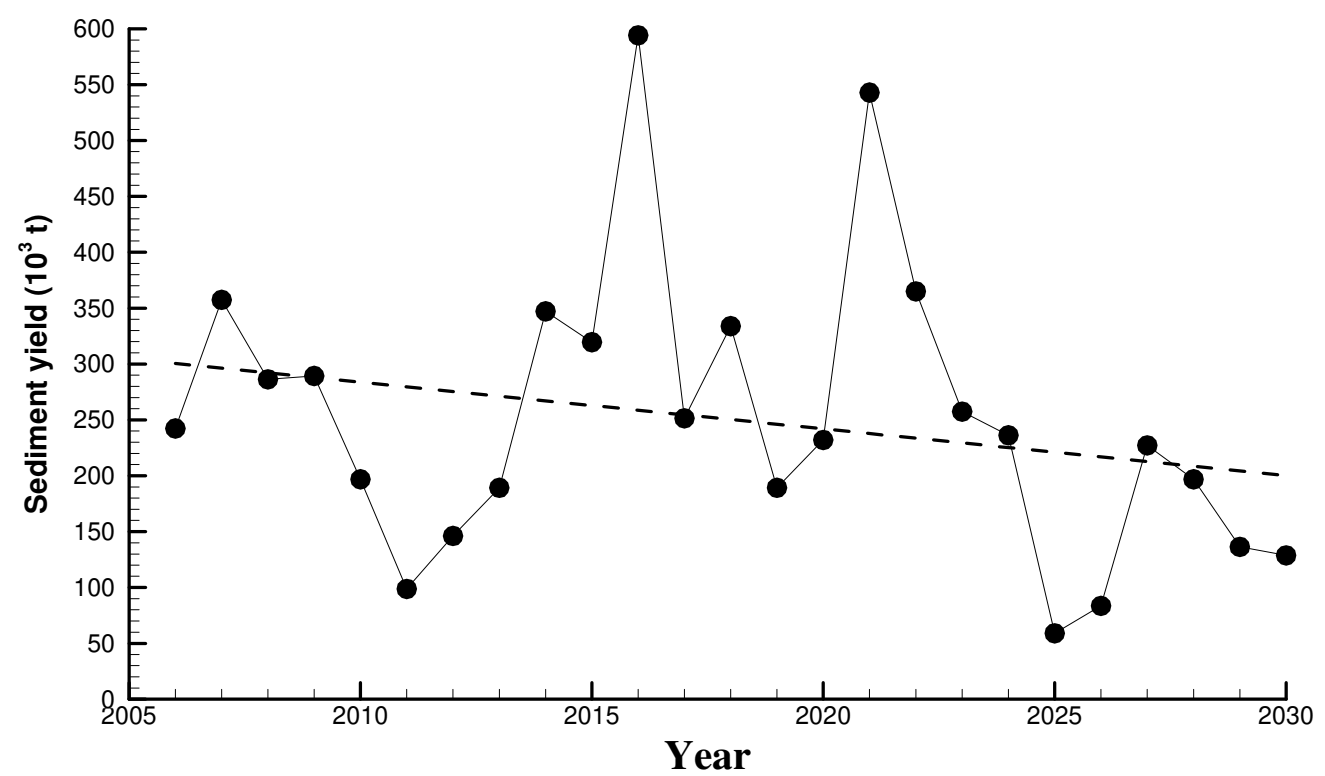

Fig. 12. Estimated sediment yield at location Toxotes for years 2006-2030. 


\section{Figures}

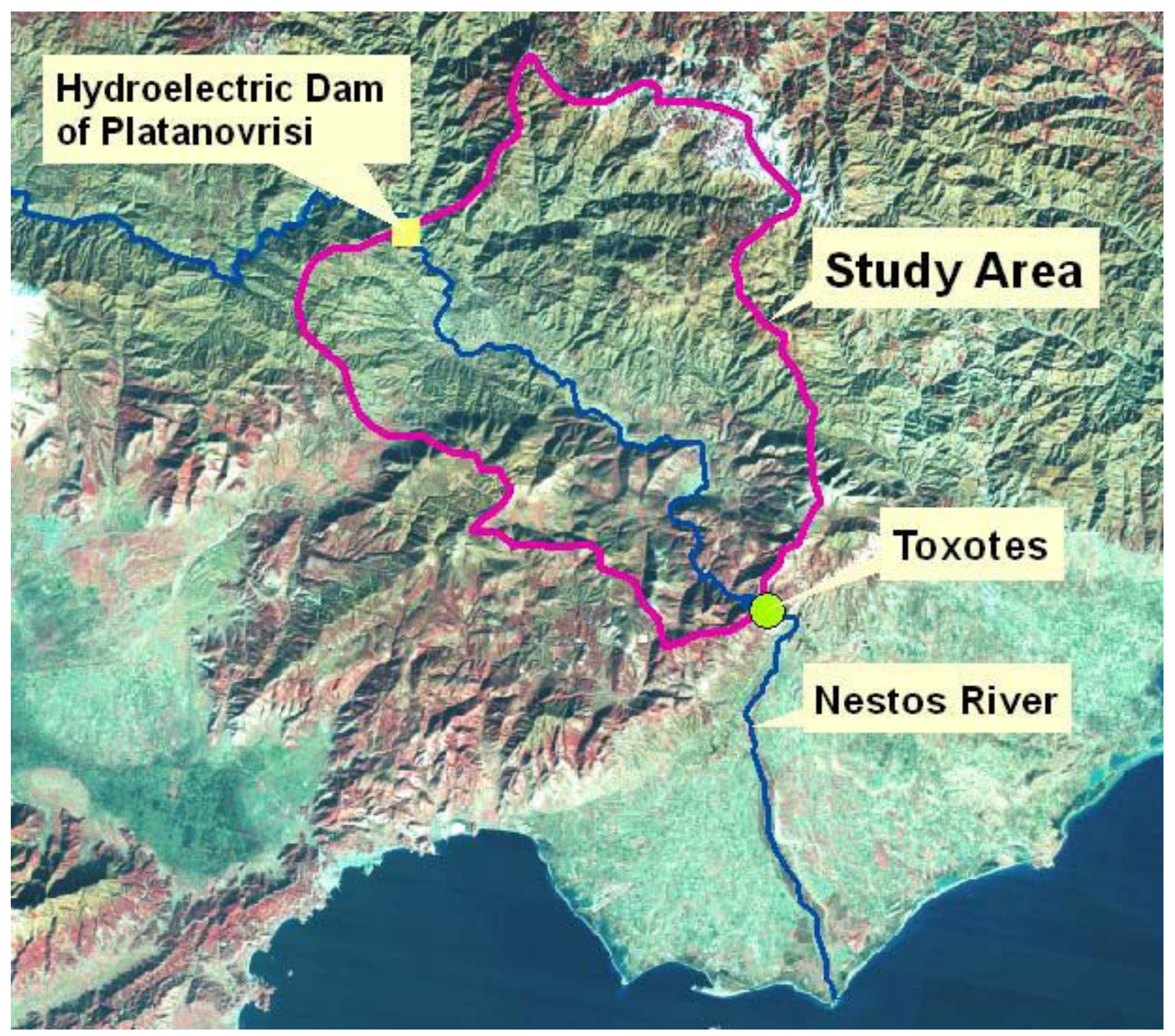

Figure 1

The study area. Note: The designations employed and the presentation of the material on this map do not imply the expression of any opinion whatsoever on the part of Research Square concerning the legal status of any country, territory, city or area or of its authorities, or concerning the delimitation of its frontiers or boundaries. This map has been provided by the authors. 


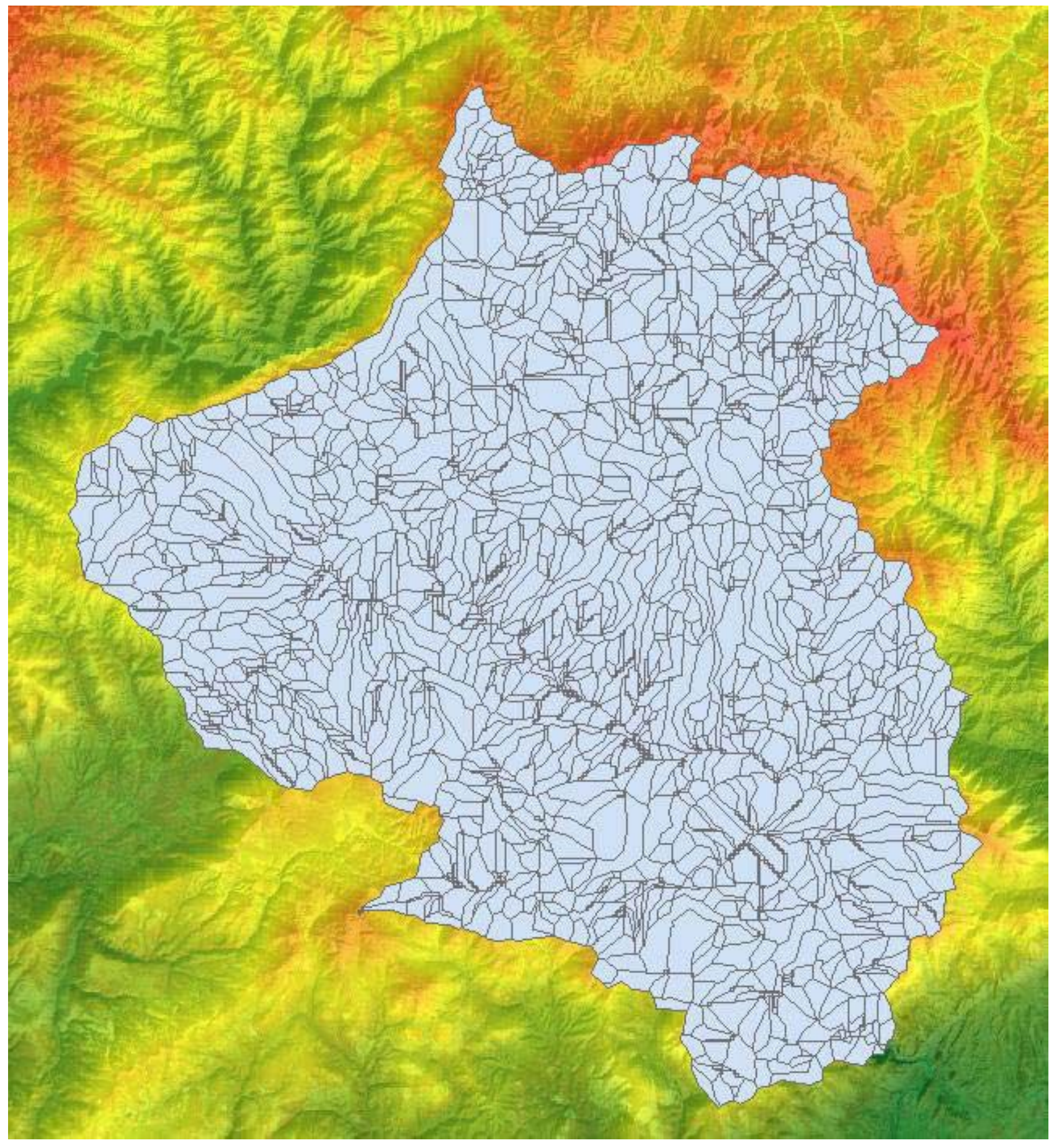

\section{Figure 2}

Area discretisation into 1568 amorphous cells. Note: The designations employed and the presentation of the material on this map do not imply the expression of any opinion whatsoever on the part of Research Square concerning the legal status of any country, territory, city or area or of its authorities, or concerning the delimitation of its frontiers or boundaries. This map has been provided by the authors. 


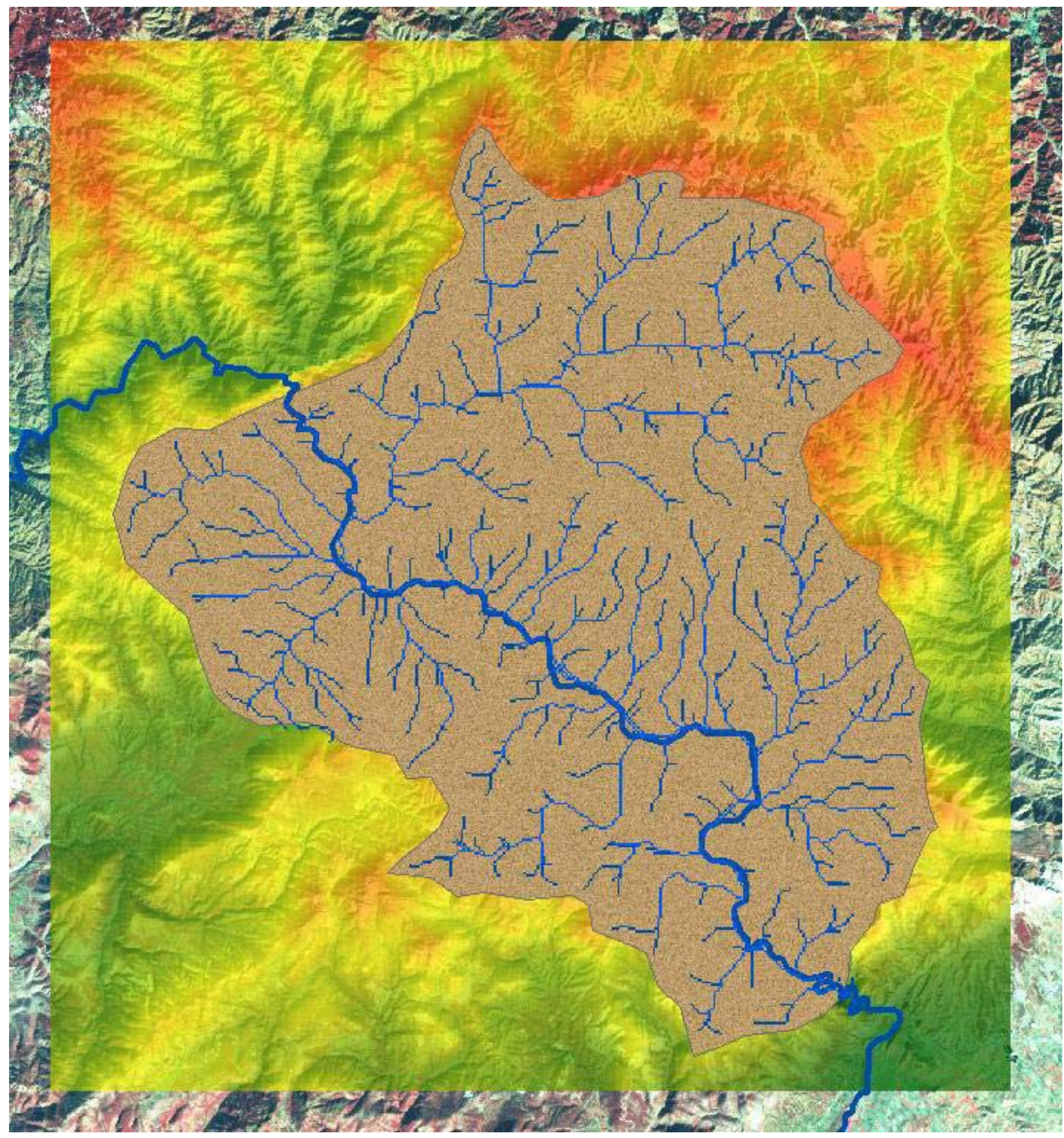

\section{Figure 3}

The drainage network of the study area (699 channel reaches). Note: The designations employed and the presentation of the material on this map do not imply the expression of any opinion whatsoever on the part of Research Square concerning the legal status of any country, territory, city or area or of its authorities, or concerning the delimitation of its frontiers or boundaries. This map has been provided by the authors. 


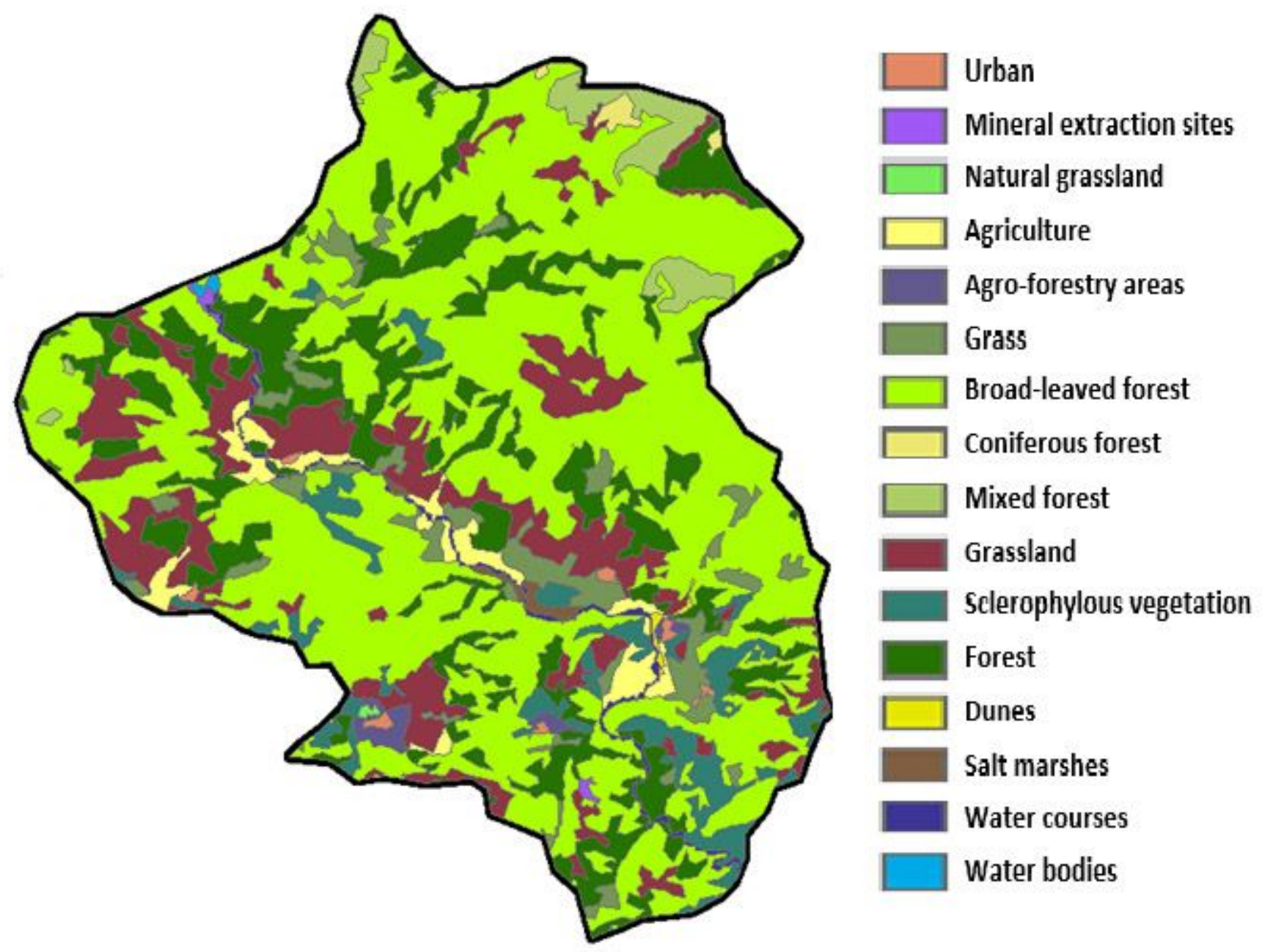

Figure 4

The land uses of the study area. Note: The designations employed and the presentation of the material on this map do not imply the expression of any opinion whatsoever on the part of Research Square concerning the legal status of any country, territory, city or area or of its authorities, or concerning the delimitation of its frontiers or boundaries. This map has been provided by the authors. 


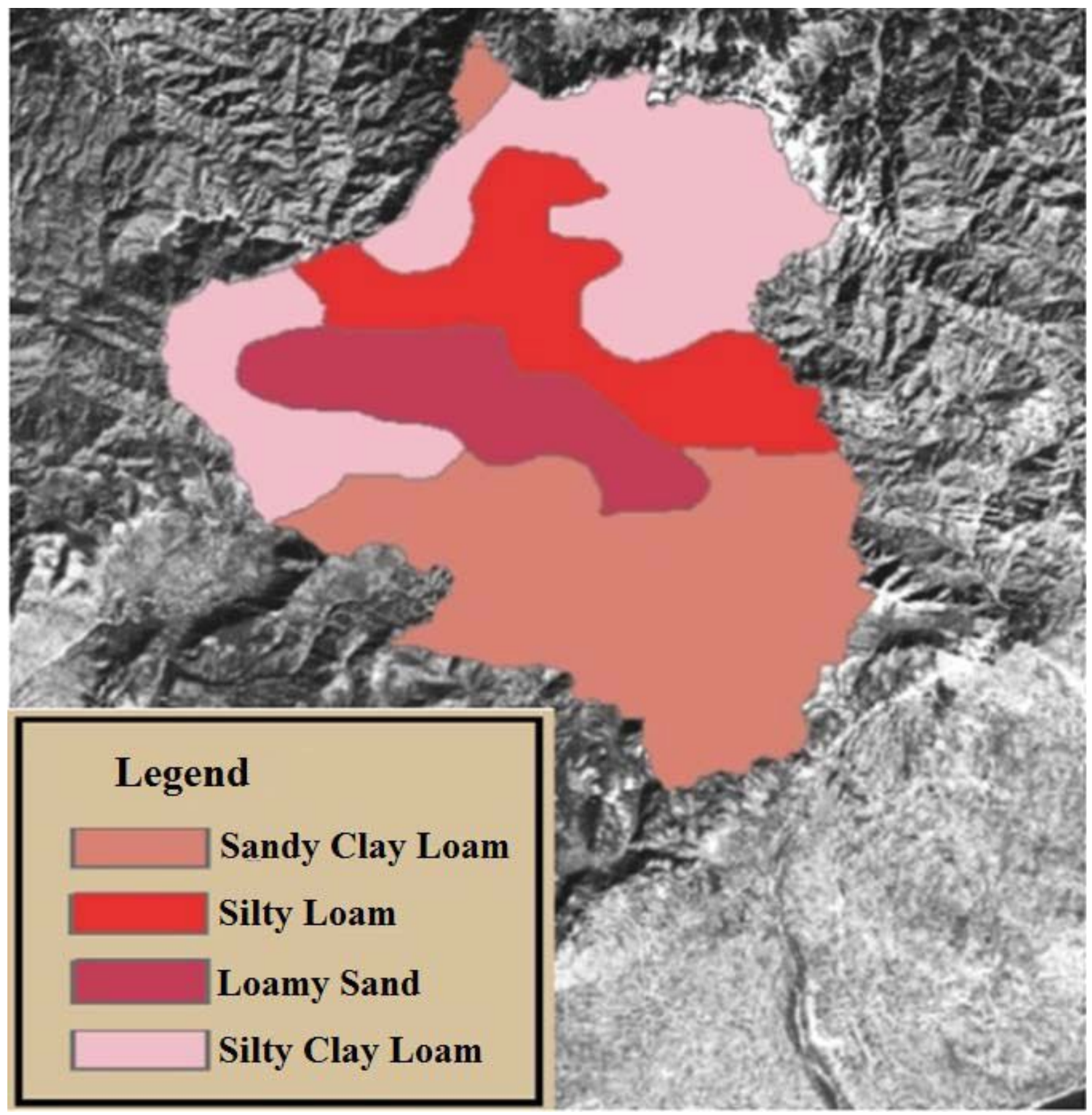

Figure 5

Soil map of the study area. Note: The designations employed and the presentation of the material on this map do not imply the expression of any opinion whatsoever on the part of Research Square concerning the legal status of any country, territory, city or area or of its authorities, or concerning the delimitation of its frontiers or boundaries. This map has been provided by the authors. 


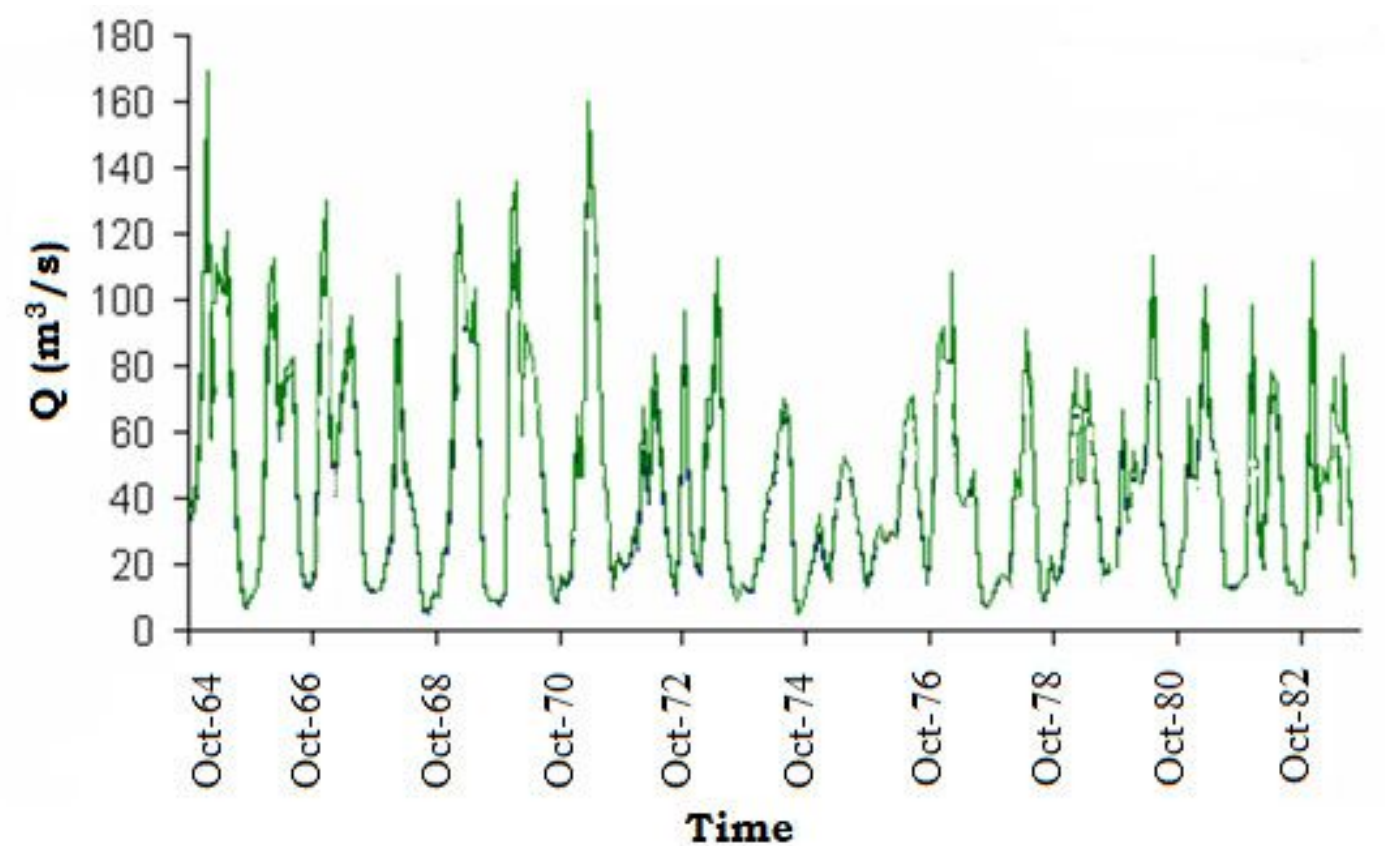

Figure 6

Mean monthly flow rate at Platanovrisi dam for the period 1964-1983.

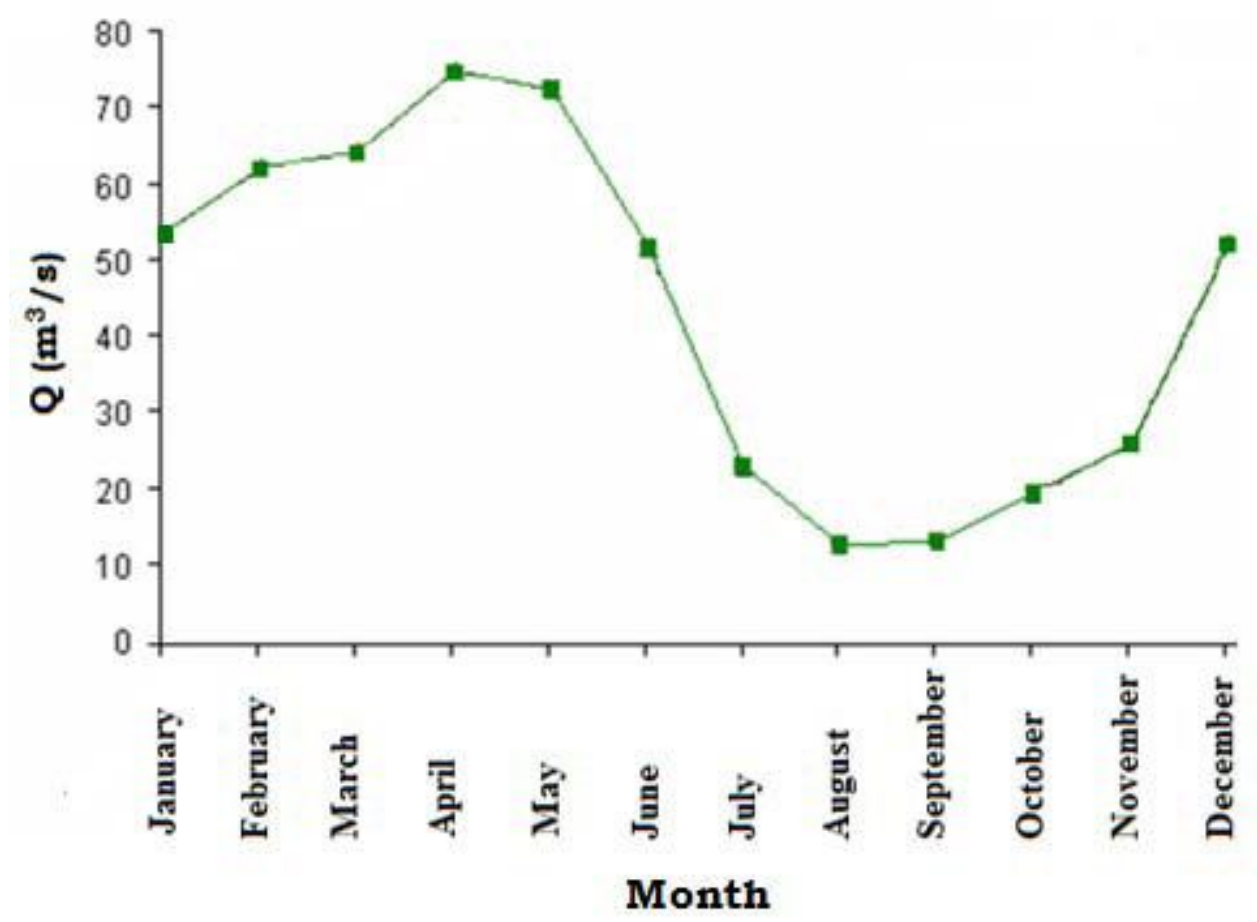

Figure 7

Average mean monthly flow rate at Platanovrisi dam for the period 1964-1983. 


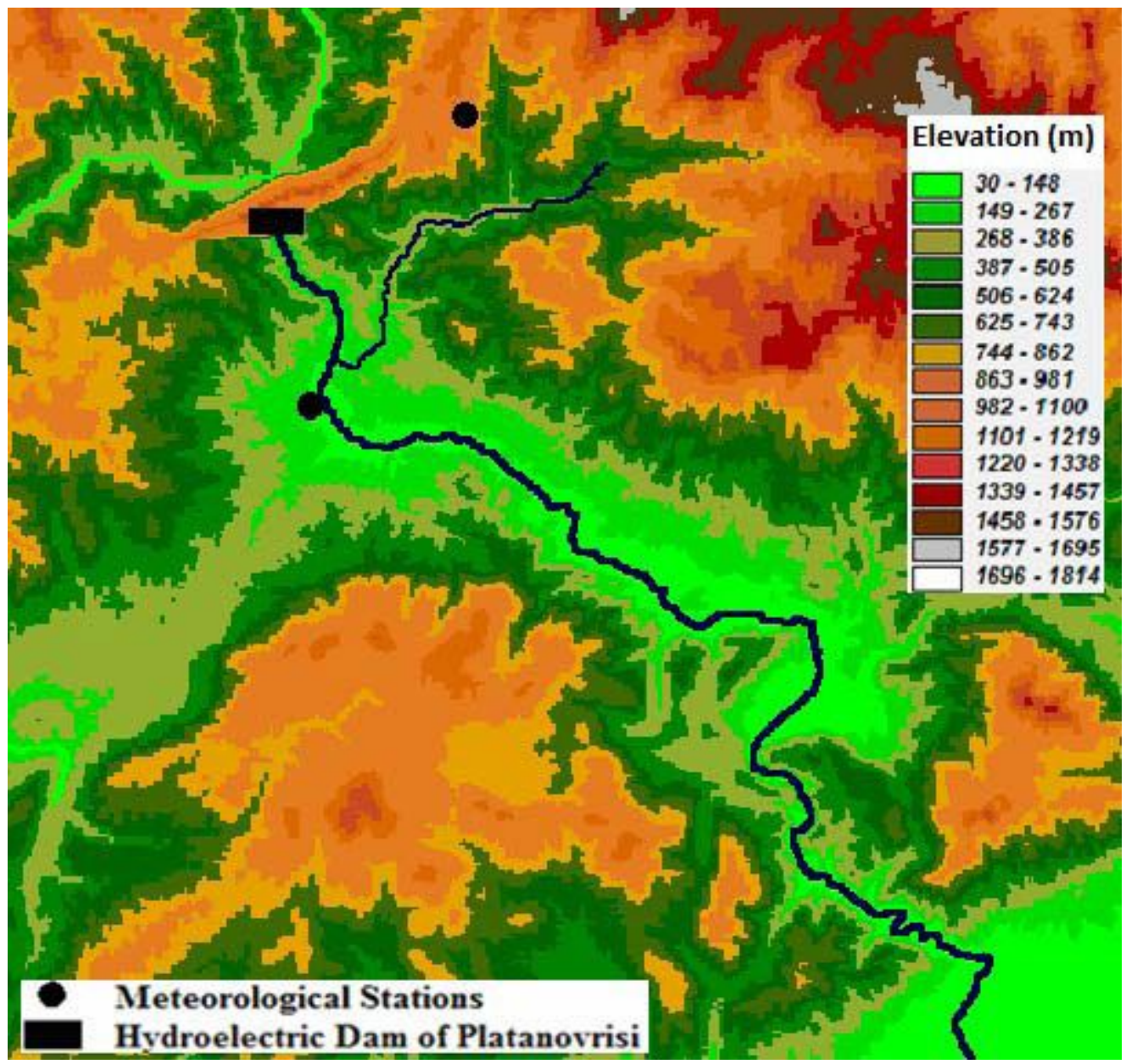

\section{Figure 8}

The study area with the two meteorological stations. Note: The designations employed and the presentation of the material on this map do not imply the expression of any opinion whatsoever on the part of Research Square concerning the legal status of any country, territory, city or area or of its authorities, or concerning the delimitation of its frontiers or boundaries. This map has been provided by the authors.

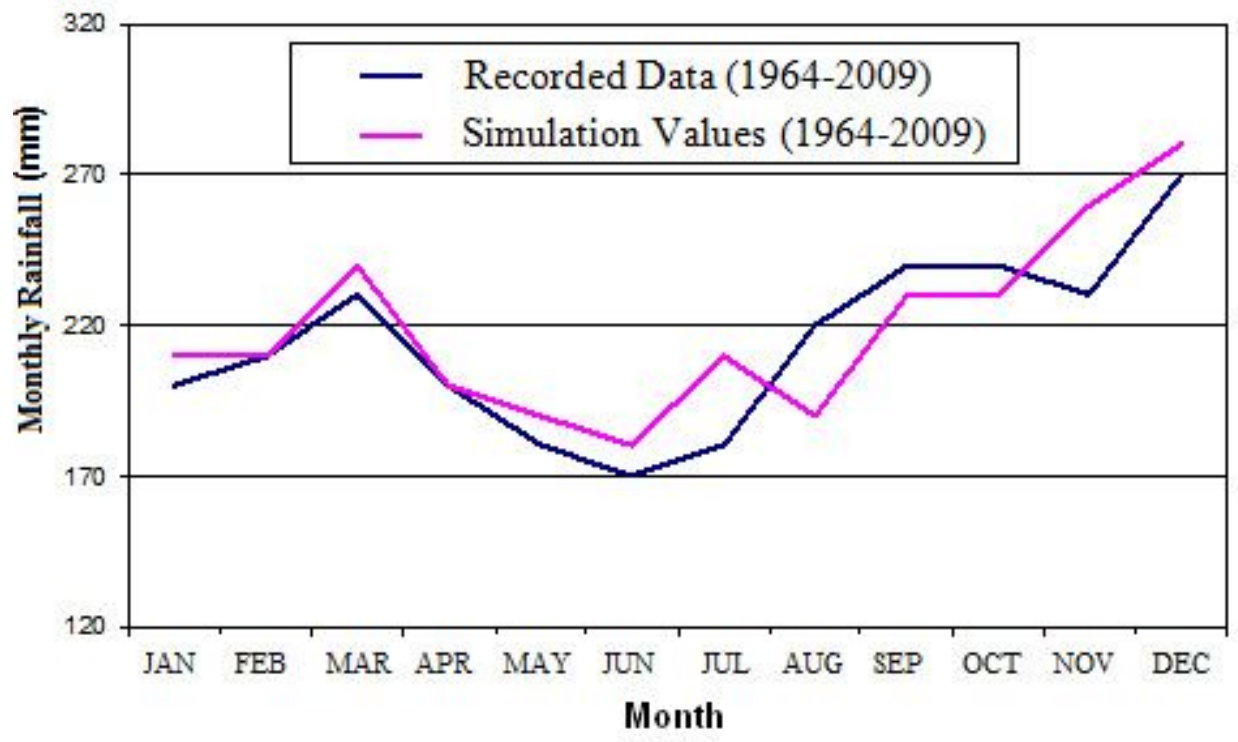


Figure 9

Maximum monthly rainfall at station 1 .

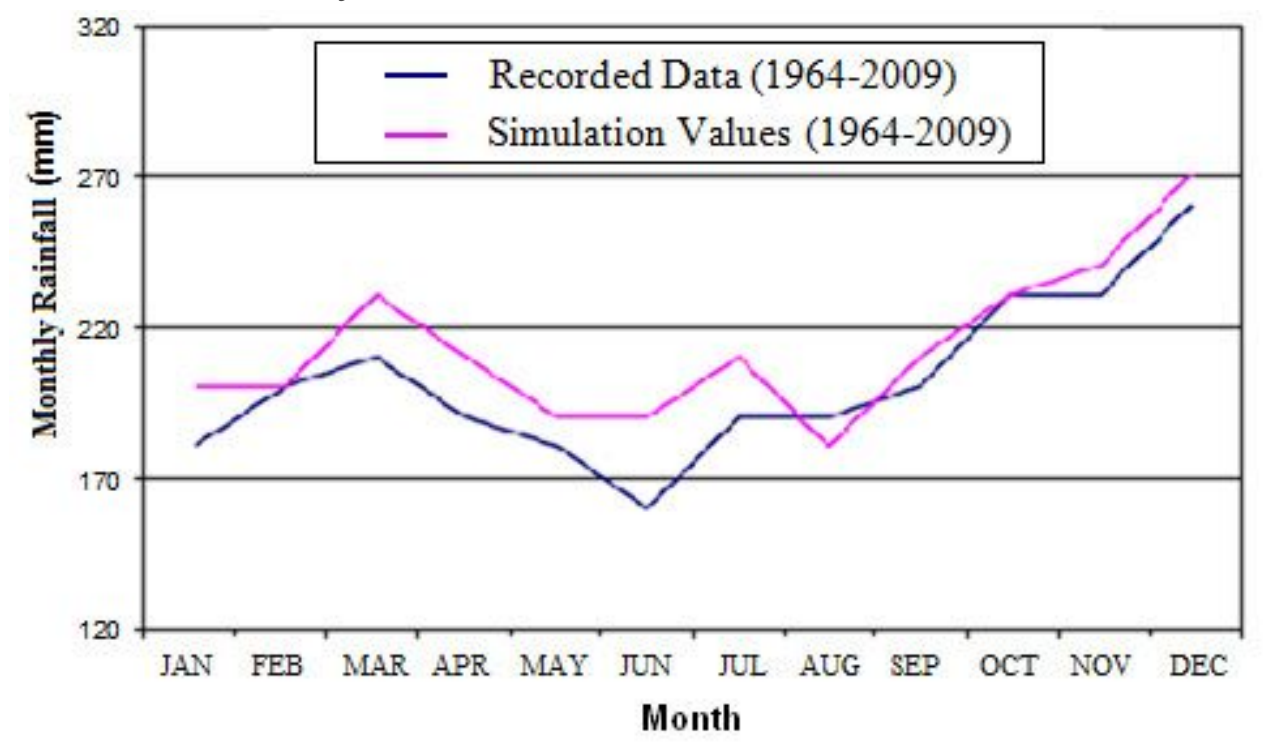

Figure 10

Maximum monthly rainfall at station 2 .
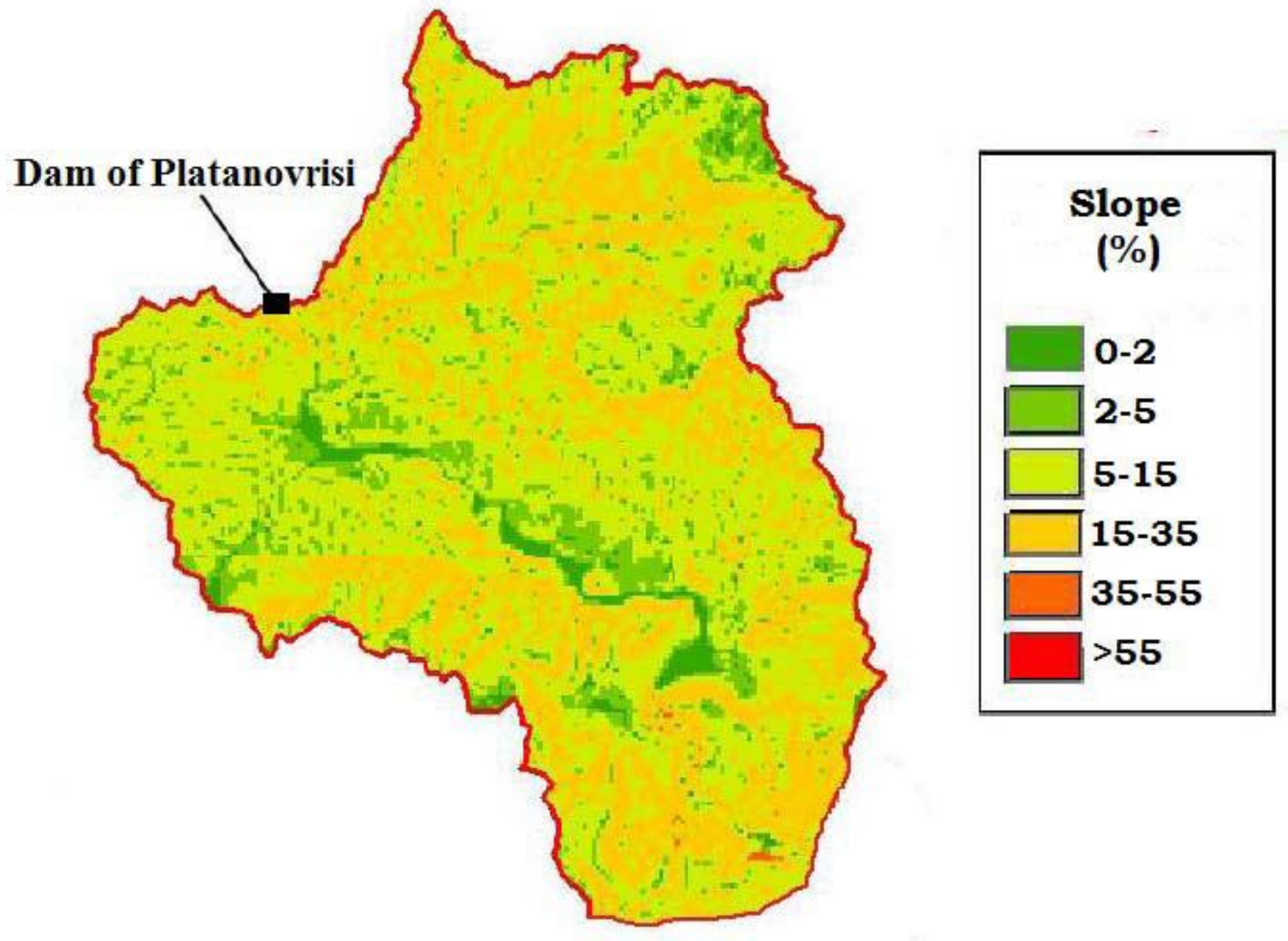


\section{Figure 11}

Terrain slopes in the study area. Note: The designations employed and the presentation of the material on this map do not imply the expression of any opinion whatsoever on the part of Research Square concerning the legal status of any country, territory, city or area or of its authorities, or concerning the delimitation of its frontiers or boundaries. This map has been provided by the authors.

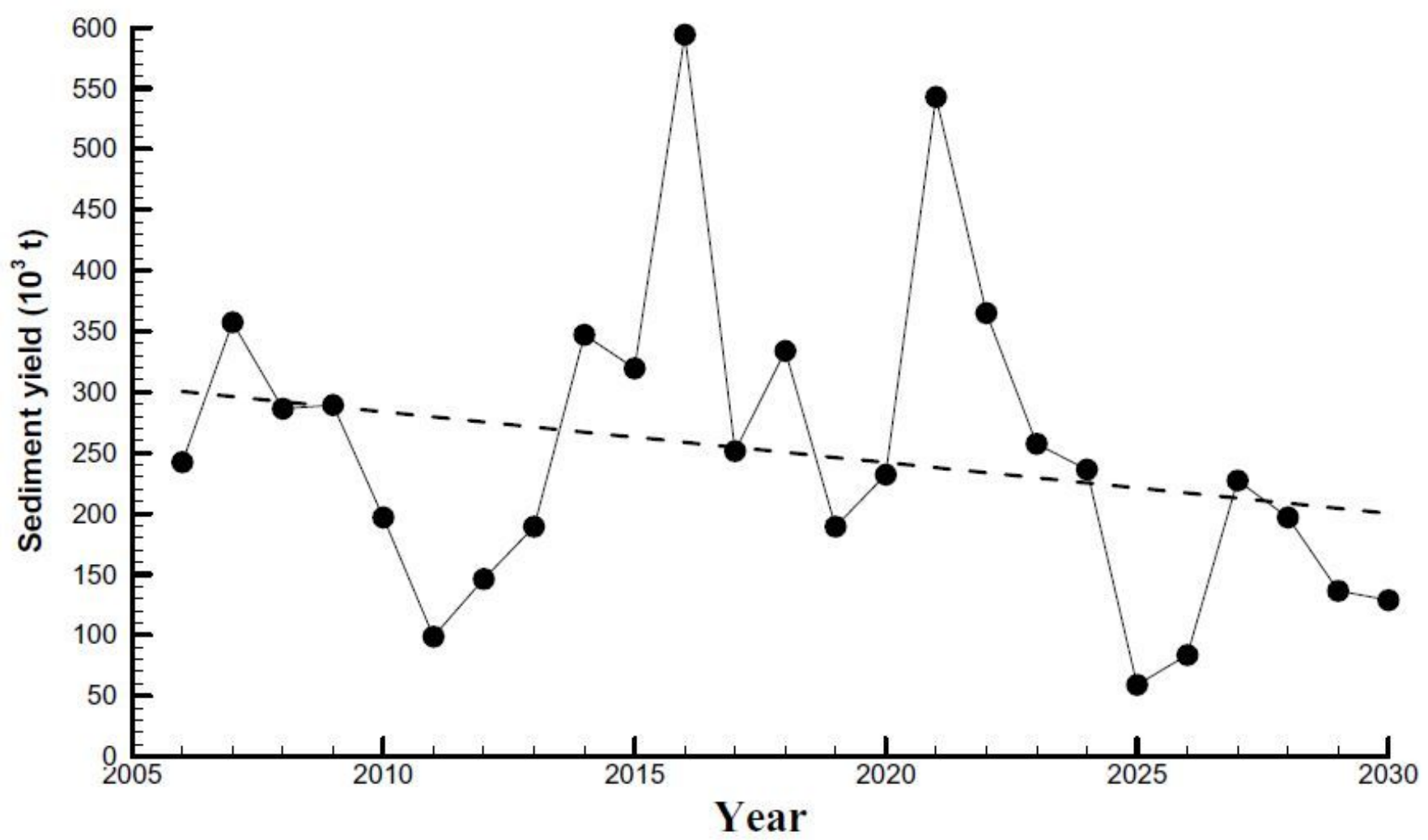

Figure 12

Estimated sediment yield at location Toxotes for years 2006-2030. 